\title{
Middle Jurassic (Bajocian) planktonic foraminifera from the northwest Australian margin
}

\author{
Marjorie Apthorpe \\ P.O. Box 814, Batemans Bay NSW 2536, Australia \\ Correspondence: Marjorie Apthorpe (marjorieapthorpe@gmail.com)
}

Received: 30 July 2019 - Revised: 14 May 2020 - Accepted: 19 May 2020 - Published: 8 July 2020

\begin{abstract}
The aim of this paper is to document three well-preserved morphotypes of Middle Jurassic (Bajocian) planktonic foraminifera from the continental margin of northwestern Australia. This location is on the southern shelf of the Middle Jurassic Tethys Ocean, and these occurrences of planktonic or meroplanktonic species are the first to be reported from the Jurassic of the Southern Hemisphere. The morphotypes include a new subspecies of Globuligerina bathoniana (Pazdrowa): Globuligerina bathoniana australiana n. ssp. Two other taxa are also described: Globuligerina altissapertura $\mathrm{n}$. sp. and Mermaidogerina loopae $\mathrm{n}$. gen. $\mathrm{n}$. sp. The microstructure of the wall is shown in scanning electron microscope images. The change from chamber to chamber in the formation of the surface ornament by secondary lamination, and its subsequent burial within the wall, is demonstrated in detail.
\end{abstract}

\section{Introduction}

The western margin of Australia contains a thick Permian to Jurassic sedimentary succession, deposited in the former East Gondwana interior rift (see Haig et al., 2017, for references). The Early to Middle Jurassic is the last depositional episode prior to continental break-up and rifting of eastern Gondwana that commenced in the late Callovian to early Oxfordian (Fig. 1). Three marine transgressions occur in the Early to Middle Jurassic succession along the northwestern continental shelf and marginal plateaux of Australia. Of these, the Bajocian transgression is the most widespread, penetrating southward as far as the Perth Basin (Apthorpe, 1994; Arkell and Playford, 1954; Bradshaw and Yeung, 1992). The overall succession has been described as consisting of fluvial to paralic sandstones and shallow marine claystone (Bradshaw and Yeung, 1992; see Hocking, 1992 for details). The subsequently rifted northwestern margin has been described as a "rifted arch system" (Veevers and Cotterill, 1978). In some areas this succession has been removed by arching and erosion at the main Callovian "break-up" unconformity on this continental margin, prior to rifting away of a continental fragment, and sea-floor spreading in the Argo Abyssal Plain (Johnson et al., 1976; Metcalfe, 2013; Veevers and Cotterill, 1978). Inshore of the northwest margin, the
Early to Middle Jurassic occurs in fault-bounded troughs and half-grabens above a thick Triassic sequence (Colwell et al., 1990, 1994; Exon and von Rad, 1994; Exon and Colwell, 1994; Exon et al., 1990). Detailed foraminiferal examination of 17 petroleum wells and one suite of dredge samples indicates that marine Early and Middle Jurassic intervals can be recognised across the continental shelf up to $450 \mathrm{~km}$ from the continental margin, south of the inferred location of the deep Tethyan ocean (Apthorpe, 1994). Wells in the rift-axis central part of the continental margin contain the thickest and most marine claystones but appear to be without planktonic foraminifera. A further $200 \mathrm{~km}$ northwest, planktonic specimens are recorded here as a small part of the foraminiferal assemblage in two Middle Jurassic dredge samples. These samples are from the rifted western margin of the Rowley sub-basin (Stagg and Exon, 1981), a wholly offshore depositional trough with a thick Triassic-Middle Jurassic sedimentary succession.

\section{Previous work on Australian Middle Jurassic foraminifera}

There is little published on the Early and Middle Jurassic foraminifera of Australia because almost all of the fully marine succession lies offshore. These offshore fau- 
nas have been studied in petroleum exploration wells and a sequence of benthic foraminiferal zones summarised in Apthorpe (1994). The earliest publication is that of Chapman (1904) on the benthic foraminifera and ostracoda from a locality in the Bajocian near Geraldton, Perth Basin, southern Western Australia (Fig. 1). Bajocian benthic foraminifera from the Geraldton area have been described by Bartenstein and Malz (2001). Quilty (1981) described possibly Jurassic benthic foraminifera from dredged samples from the Exmouth Plateau, but subsequent authors (Kristan-Tollmann and Gramann, 1992) have regarded these assemblages as more probably Triassic in age. Kristan-Tollmann (in Colwell et al., 1994) described one Early Jurassic dredge sample from the northern margin of the offshore predominantly Late Triassic Exmouth Plateau. Lynch (in Exon et al., 1990) and Wells (in Colwell et al., 1990) illustrated and briefly listed benthic Jurassic foraminifera in offshore dredge samples obtained by Geoscience Australia (then the Bureau of Mineral Resources - BMR) in 1990 (see below for details).

\section{Sample material and age}

The $>80$ specimens reported here come from small portions of two submarine dredge samples, BMR 95/DR7/8 and BMR 96/DR28/16, dredged by Geoscience Australia (formerly the Australian Geological Survey Organisation, formerly the Bureau of Mineral Resources, Geology and Geophysics - BMR) during geophysical and geological surveys of the northern Exmouth Plateau and offshore Canning Basin carried out as BMR Cruises 95 and 96 in 1990 (Colwell et al., 1990; Exon et al., 1990). The BMR 95/DR7/8 sample was dredged at a water depth of 4530 to $3900 \mathrm{~m}$ on the northeastern wall of Mermaid Canyon, the haul starting at $16^{\circ} 18.9^{\prime} \mathrm{S}$, $118^{\circ} 22.2^{\prime} \mathrm{E}$ and ending at $16^{\circ} 18.2^{\prime} \mathrm{S}, 118^{\circ} 24.3^{\prime} \mathrm{E}$ (Fig. 2). The second sample studied, from the later BMR Cruise 96, designated BMR 96/DR28/16, is part of a dredge haul from a water depth range of 4530 to $3500 \mathrm{~m}$, also from the northeastern wall of Mermaid Canyon. This haul started at $16^{\circ} 18.496^{\prime} \mathrm{S}, 118^{\circ} 23.419^{\prime} \mathrm{E}$, and ended at $16^{\circ} 18.00^{\prime} \mathrm{S}$, $118^{\circ} 24.70^{\prime} \mathrm{E}$.

The initial dredging (BMR 95/DR7/8) recovered a "small" sample of soft puggy black silty Jurassic claystone mixed with Pleistocene and other Cenozoic pale grey soft sediment (a very large quantity of other rock types, mostly non-marine, was also recovered in the dredge haul as cobbles). The unconsolidated marine Jurassic sample contained a rich wellpreserved foraminiferal assemblage, on which a preliminary report was published by Lynch (in Exon et al., 1990). David Lynch passed the heavily washed residue and his picked slides of this sample to the author for further study.

The second sample studied (BMR 96/DR28/16 A and B) comprises two subsamples of a fissile dark grey silty mudstone (amongst many other lithologies). The mudstone is free of younger contamination and contains planktonic spec- imens. The fauna in this second sample was not as well preserved, being largely infilled with pyrite (see Sect. 4), and most of the comments relate to BMR 95/DR7/8.

The age of the Jurassic assemblages, if foraminiferal evidence from the Northern Hemisphere is used, is most likely Bajocian, or less likely, early Bathonian. This age estimate is based on the presence of Garantella aff. asteriginoides Kaptarenko-Chernousova (reported from the late Bajocian), Garantella sera Pazdrowa (late Bajocian-early Bathonian), Lenticulina micropunctata (Frentzen) (Bajocian) and L. cf. munkae Brand and Ohmert (Bathonian). Based on the abundance of Garantella spp. and the absence of both Epistomina spp. and Lenticulina dorbignyi, in the context of the Australian Jurassic marine incursions (Apthorpe, 1994), a Bajocian age is considered probable.

An examination of the calcareous nannoplankton by Richard Howe (personal communication, 1994) placed sample BMR 95/DR7/8 at the base of the early Bajocian Watznaueria britannica zone of Bown et al. (1988) on the basis of the presence of early forms of $W$. britannica. A slightly older age determination on material from the same dredge sample, and also from BMR 96/DR28/16, has been given by Shafik (1994). He determined the samples as the uppermost Lotharingius contractus sub-zone of Bown et al. (1988) on the basis of the presence of transitional forms between $L$. contractus and W. britannica. No specimens assignable to typical $W$. britannica were said to be present.

Because there is no information on the ranges of Australian Bathonian-Bajocian foraminifera from continuously fossiliferous well sections, the nannoplankton age determinations of earliest Bajocian have been accepted here. This is also consistent with palynological evidence from BMR 96/DR28/16, which yielded the early Bajocian Dissimulodinium caddaense dinoflagellate zone of Helby et al. (1987) (John Backhouse, personal communication, 2003)

\section{Material and methods of study}

The samples are submarine dredge samples recovered by Geoscience Australia, first studied shipboard and reported by Lynch (in Exon et al., 1990) and Wells (in Colwell et al., 1990). The sample nomenclature format is based on Table 2 of Colwell et al., 1994, with the addition of the prefix BMR. The first two numbers refer to the BMR cruise number (95 or 96); the second number is the dredge number (e.g. 7), and the third number (e.g. 8) is the rock type within the dredge haul (note that the "rock type" 16 included in bagged sample BMR 96/DR28/16 consists of several different mudstone varieties, including grey and fissile, silty, and ferruginous). This nomenclature has appeared in variable forms in the literature describing these dredge samples, with various authors inserting 0 within the sample number (for example, DR 07/8: Lynch, in Exon et al., 1990, and 95DR/07-08: Shafik, 1994; both variants refer to the same sample studied here). The 


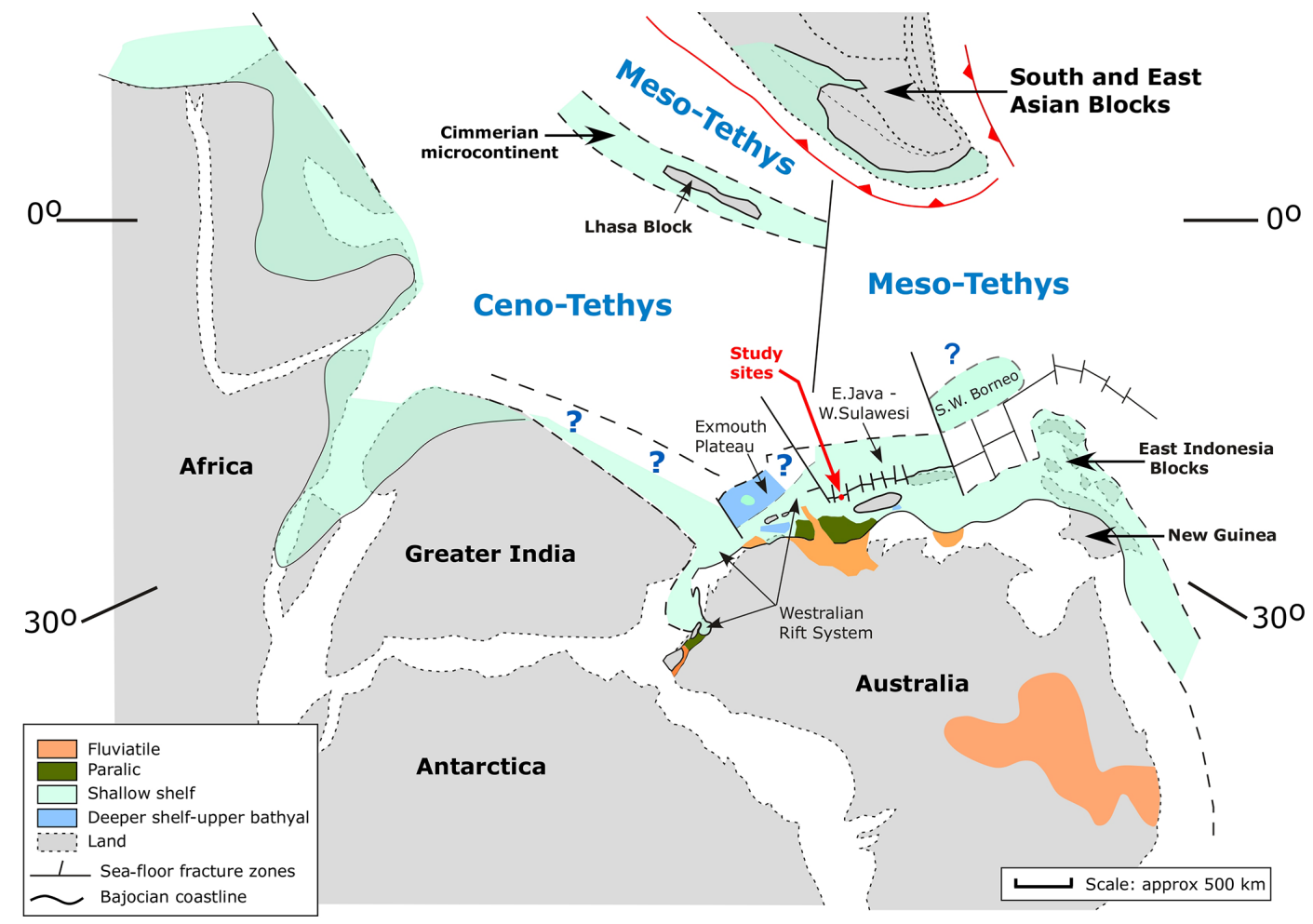

Figure 1. Palaeogeographic reconstruction of the southern shoreline of the Tethys in the early Bajocian (based on data in Metcalfe, 2013; Bradshaw and Yeung, 1992; Apthorpe, 1994; Powell et al., 1980; Exon and Colwell, 1994; Johnson et al., 1976; and Veevers and Cotterill, 1978). Study sites are shown at the arrowed red dot.

samples are referred to in this paper as BMR 95/DR7/8 and BMR 96/DR28/16.

The illustrated specimens have been deposited in the Western Australian Museum, Perth, Australia, under the catalogue numbers WAM 18.3 to WAM 18.26 and WAM 19.1. The second number starting with " $\mathrm{M}$ " attached to the specimens in the figure captions is the working number on the photographic records, which was used prior to museum cataloguing.

Planktonic specimens constitute less than $1 \%$ of the total foraminifera in the soft mud sample BMR 95/DR7/8. The shipboard sample was initially selectively picked due to the number of fragmentary specimens and the presence of younger material. The original dredge material was resampled and several subsamples were processed by washing in water only. Described specimens come from both the shipboard sample and subsequent reprocessed samples. One of the subsequently processed subsamples weighing $21 \mathrm{~g}$ (see below) was split, and one-fifth was totally picked for foraminifera and counted. This count of 942 Jurassic foraminifera yielded 8 planktonic specimens $(0.84 \%$ of the total), which are mostly very small in size. By extrapolation, the original $21 \mathrm{~g}$ sample yielded at least 4700 foraminifera. Another subsample processed from $7.5 \mathrm{~g}$ of the original material and partially picked yielded 500 foraminifera per gram of original sediment. Of these, $0.44 \%$ are planktonic specimens. The planktonic specimens appear to be aragonite, having a yellowish grey or brown colour similar to that of aragonitic benthic specimens in the same sample, and the tests are empty and fragile; thus, many are broken in the samples studied. In the mudstone samples of BMR 96/DR28/16, planktonics are a little more frequent, around $1 \%$, but more poorly preserved due to internal fillings of pyrite that have caused the dissolution of some walls and the recrystallisation of others. Of some 80 planktonic specimens picked (including fragmentary ones), a total of 54 specimens from both samples have been photographed on the Philips 505 scanning electron microscope (SEM). Most photographed specimens are from sample BMR 95/DR7/8, which has variable but mostly better preservation.

Clearly, in a study based on samples dredged from the walls of a sea-floor canyon, the issue of possible contamination needed to be resolved as soon as the first "Jurassic" planktonic specimens were found. Moderate numbers of late Cenozoic specimens were present in the shipboard-processed sample made available to the author for study. The following steps were taken to verify that the specimens described herein were not small Cenozoic contaminants from the sea floor.

1. The original sample (BMR 95/DR7/8) was resampled at the Australian Geological Survey Organisation (now 


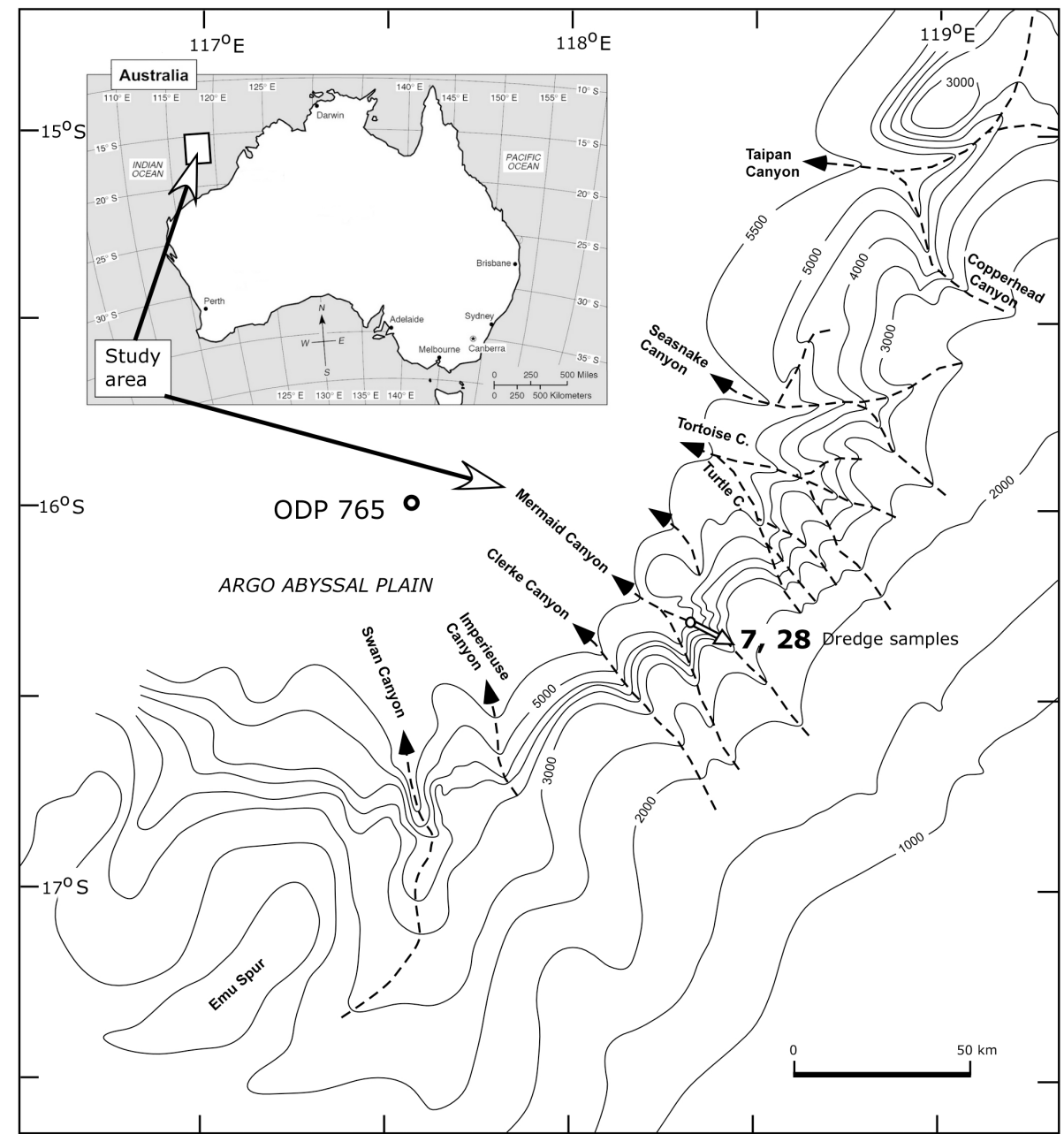

Figure 2. Locality of submarine dredge samples BMR 95/DR7/8 (7) and BMR 96/DR28/16 (28) (in the rifted Rowley sub-basin) and the approximate dredged distance in the Mermaid Canyon on the continental slope of northwestern Australia. Bathymetry in metres.

Geoscience Australia) by the author in 2001. The material, originally described in 1990 as a "small amount" of soft black claystone, had by 2001 dried and hardened into several lumps of sediment. When examined under the microscope, deformed pieces of a dark brownish grey claystone can be seen, surrounded by swirls and layers of lighter brownish grey claystone containing robust and large, mainly Plio-Pleistocene planktonic foraminifera, which are severely affected by dissolution due to the present water depth $(>4000 \mathrm{~m})$. Several small subsamples of the central darker claystone were dug out under the binocular microscope using a sharp blade. These subsamples were washed in water by the author using carefully cleaned and checked 125 and $63 \mu \mathrm{m}$ mesh sieves. Picking of two of these small samples (A, $7.6 \mathrm{~g}$ of sample processed; C, $21 \mathrm{~g}$ of sample processed) yielded (extremely rare) planktonic specimens of Jurassic morphology. The amount of younger contamination in these samples was reduced but still present.

2. The locality was re-dredged during a later BMR cruise (Cruise 96), and Jurassic foraminifera were recorded by Wells (in Colwell et al., 1990) in two samples (BMR 96/DR28/15 and BMR 96/DR28/16). In 2001 the author was able to resample these bagged samples. The samples proved to be variable dark grey and reddish grey claystones, recovered as multiple blocks up to $15 \mathrm{~cm}$ long, with traces of younger contamination in hollows in the surface. One sample was of much softer fissile claystone, now impregnated with gypsum crystals as a result of seawater impregnation; this sample was coated with younger mud. The subsamples taken from these bags were completely cleaned under the microscope of all visible traces of possible Plio-Pleistocene mud by the author by washing and scraping with a blade. The cleaned pieces of mudstone were soaked in water and washed by the author through a new $63 \mu \mathrm{m}$ 
sieve. The portions of sample BMR 96/DR28/15 sampled and processed by the author proved to be barren of microfauna, suggesting that Wells' foraminiferal sample from DR28/15 was from a different mudstone lithology. Reprocessing of a $75 \mathrm{~g}$ sample from BMR 96/DR28/16 yielded a rich Jurassic microfauna (as reported by Wells in 1990), including a number of planktonic specimens of identical form to those previously found in BMR 95/DR7/8. The preservation of some of these later-found specimens from BMR 96/DR28/16 is not as good, as most of the fauna is infilled with pyrite. Several of the best-preserved specimens, with calcareous walls intact and not heavily etched, have been imaged by SEM.

3. The composition and preservation of some of the white, Plio-Pleistocene and other Cenozoic contaminants in the original sample of BMR 95/DR7/8 were investigated by SEM (Most of the younger material consists of fragmentary thick-walled Sphaeroidinella spp., Globorotalia cultrata, Globorotalia tosaensis and Globorotalia tumida, which were ignored.) Small specimens of Globigerinoides ruber, G. quadrilobatus, Globigerina sp., Globigerinita glutinata and Hastigerina siphonifera were examined in order to compare the preservation and size of wall structures with those of the Jurassic specimens. Most of the Plio-Pleistocene specimens show considerable dissolution effects due to the present water depths, as well as much thicker wall structures. Specimens of Globigerinita glutinata from BMR 95/DR7/8, and of Gallitellia vivans from other samples in the author's collection provided comparisons with the Jurassic wall textures but confirmed that these species were not part of the "Jurassic" assemblage. These images are not reproduced here.

\section{Palaeogeography}

The dredge samples are located on the rifted continental margin of northwestern Australia, which is dissected by submarine canyons (Fig. 2). Prior to late Callovian-Oxfordian rifting, to the north of this location lay a joined continental block labelled "East Java-West Sulawesi" in the reconstruction of Metcalfe (2013), previously named "Argoland" in older reconstructions (Fig. 1). This area formed part of a wide continental shelf and basin region on the southern margin of the Tethys. The palaeoenvironment at the sample locations is interpreted to have been a shallow open marine shelf based on the very low percentage $(<1 \%)$ of planktonic specimens, the abundance of miliolid foraminifera and a great diversity of other benthic calcareous foraminifera. Aragonitic benthics are prominent. Sample BMR 95/DR7/8 A, the $7.5 \mathrm{~g}$ sample processed after resampling, contains $35.8 \%$ miliolids and $53.9 \%$ aragonitic benthic foraminifera. The percentage of planktonic foraminifera in the totally picked portion of the sample was $0.4 \%$. Based on the picked portion of the sample, the original sediment contained approximately 500 foraminifera per gram of sediment. The presence of broken bulla structures on all three foraminiferal species described here suggests a planktonic mode of life, at least in their reproductive phase. Other microfossil remains in BMR 95/DR7/8 include echinoid spines, small ostracods, abundant algal fragments and micromolluscs including ammonites. The samples are rich in fresh mica flakes, indicating riverine influx onto the shelf (see Fig. 1; also Bradshaw and Yeung 1992).

\section{Previous work on Bajocian and older planktonic foraminifera}

Reviews of Jurassic planktonic foraminifera are given by Grigelis and Gorbatchik (1980), Stam (1986), Simmons et al. (1997), Hart et al. (2002, 2012), BouDagherFadel (2015), Gradstein (2017), and Gradstein et al. (2017a, b). Other key papers are Grigelis $(1958,2016)$, Bignot and Guyader (1971), Görög (1994), and Wernli (1995). A review of the literature on Jurassic planktonic foraminifera is beyond the scope of this paper, which focuses on the early Bajocian. This is early in the evolutionary development of Jurassic planktonic foraminifera, the origins of which are still unclear. Fuchs (1967) described a number of Triassic species as probably meroplanktonic or as probable ancestors of planktonic forms, but his opinions and genera have been largely rejected by later researchers (Hart et al., 2012). Morozova described high-spired Globigerina (Conoglobigerina) avarica from the Bajocian-Bathonian boundary in Dagestan (Morozova and Moskalenko, 1961). Wernli (1988) described "protoglobigerinids" in thin sections from the Toarcian and Aalenian and pointed out the presence of secondary lamination ("concurrent test") in Aalenian to Bajocian forms. Wernli and Görög $(1999,2000)$ described protoglobigerinids from Bajocian limestones in Hungary. Hart et al. (2003) hypothesised an origin from the benthic Oberhauserella, leading to the evolution of Conoglobigerina as the first planktonic genus late in the Bajocian, but this timing seems unlikely given that Globuligerina is already present in the early Bajocian (this paper; Wernli and Görög, 1999). Simmons et al. (1997) provided an overview of the then-known occurrences of Jurassic planktonic foraminifera and defined the differences between the important genera Conoglobigerina and Globuligerina solely on the basis of apertural shape. BouDagherFadel (2015) continued this approach, defining the difference between Conoglobigerina and Globuligerina on apertural characters consisting solely of "an interiomarginal low arch" in the former and the presence of a "loop-shaped bulimine" aperture "with a distinct rim" in the latter genus. This conflicts with the refiguring of types of the widespread Globuligerina bathoniana by Hart et al. (2012), which shows the aperture to be a medium to high arch. Gradstein et al. (2017a, 
b) reviewed the scope of known Jurassic planktonics with new SEM illustrations of some species and refigured publication plates of other authors illustrating previously described species. Unfortunately this synthesis did not describe or illustrate the variability of key species. Hart et al. (2012) point out that Huddleston (1982) drew attention to the fact that the type species of Globuligerina was defined as Globigerina oxfordiana Grigelis 1958, emended Bignot and Guyader 1966, which was a form with a high loop-shaped aperture and was not the original concept of Globigerina oxfordiana Grigelis 1958. Grigelis (2016) redescribed Globigerina oxfordiana, the type species of Globuligerina. His 2016 SEM photograph of the topotype (Grigelis, 2016, plate 1, fig. 3) shows the aperture as a wide, fairly low umbilical arch, in conflict with the generic definition of a high, loop-shaped aperture proposed by Simmons et al. (1997), which followed the probable misidentification of Bignot and Guyader. Photographs of paratypes (Grigelis, 2016, plate 4, figs. 1, 3, 4) show higherarched apertures excentrically positioned within the umbilicus but not loop-shaped.

Even a brief review of the literature (Bignot and Guyader, 1971; Grigelis and Gorbatchik, 1980; Stam, 1986; Görög, 1994; Wernli, 1995; Simmons et al., 1997; Hart et al., 2002, 2012; BouDagher-Fadel, 2015; Grigelis, 1958, 2016; Gradstein, 2017; Gradstein et al., 2017a, b) demonstrates the wide divergence of opinion surrounding the key features used to define Jurassic planktonic species and genera. It is noted from these literature sources that descriptions of morphological characters overlap or show transitions between species and even genera and that apertures vary considerably within species. Gradstein et al. (2017a), in differentiating between the two widely recognised genera Conoglobigerina and Globuligerina, distinguish the two genera by wall surface ornament, despite this feature often being poorly preserved. These authors consider test shape, chamber arrangement and shape, and the height/diameter ratio to be key elements for recognition at a species level only. They also use an assemblage concept of species, with wide but undefined variations in some characters within one species. Wernli and Gorog (2007) considered the shape and position of the aperture and the wall ornament to be important characteristics for generic differentiation. (However, both characters are difficult to apply except in very well-preserved Jurassic specimens.) Other characters they considered to be so variable as to apply at specific level only. Some species have been described from thin sections and acetolysis of limestones (Wernli and Görög 1999), which prevents the consideration of wall ornament. In contrast to Wernli and Görög, Gradstein et al. (2017a) consider apertural shape to be irrelevant for generic definitions and variable even within single species.

Given such a wide divergence of opinion on the definition of described Jurassic species, only comments applicable to Australian morphotypes are offered here. The characteristics found most useful and distinctive for the Australian material are applied in this study. These are the following: (at generic level) the coiling mode and the number of chambers in each whorl; the axial height of the test; the chamber shape; the wall ornament; and (at species level) the apertural shape. The Australian morphotypes illustrated here fall into three forms, described as new. Comparisons are made with those previously described species that appear most similar, without any comment being implied on their generic placement.

\section{Systematic descriptions}

Globuligerina bathoniana australiana n. ssp. (Fig. 3: 1-14; Fig. 6: 4-5; Fig. 8: 9-11, 13; Fig. 9: 4-7; Fig. 10: 1-10).

\section{Synonymy}

?1969 Globigerina bathoniana Pazdrowa part: p. 47; only fig. 5a-f, specimen DG-5; plate II, fig. 5, specimen DG-12.

\section{Holotype}

Specimen WAM 18.10/M10-21 (Fig. 3: 6, 9).

Paratypes

Specimens WAM 18.11/M2-17 (Fig. 3: 1-3); WAM 18.12/M64-13 (Fig. 3: 4-5); WAM 18.13/M73-09 (Fig. 3: $10-11,14)$.

\section{Type locality}

Sample BMR 95/DR7/8, dredged at a water depth of 4530 to $3900 \mathrm{~m}$ on the northeastern wall of Mermaid Canyon, offshore of northwestern Australia; the dredge haul starting at $16^{\circ} 18.9^{\prime} \mathrm{S}, 118^{\circ} 22.2^{\prime} \mathrm{E}$ and ending at $16^{\circ} 18.2^{\prime} \mathrm{S}$, $118^{\circ} 24.3^{\prime} \mathrm{E}$.

\section{Derivation of subspecies name}

Austral, meaning southern, referring to the location.

\section{Diagnosis}

The test is initially a very low trochospire of four to five chambers around the proloculus, changing in the second whorl to a very high trochospire with only three chambers per whorl. Height of spire up to $0.29 \mathrm{~mm}$. Wall with prominent tubercules and/or pseudomuricae; microperforate; pronounced secondary lamination developed. Wall sculpture and the height of ornament vary throughout ontogeny as secondary lamination develops.

\section{Description}

High trochospiral calcareous globigerinid test, small, test diameter ranging from 0.11 to $0.22 \mathrm{~mm}$, height usually slightly exceeding maximum diameter, ranging from 0.12 


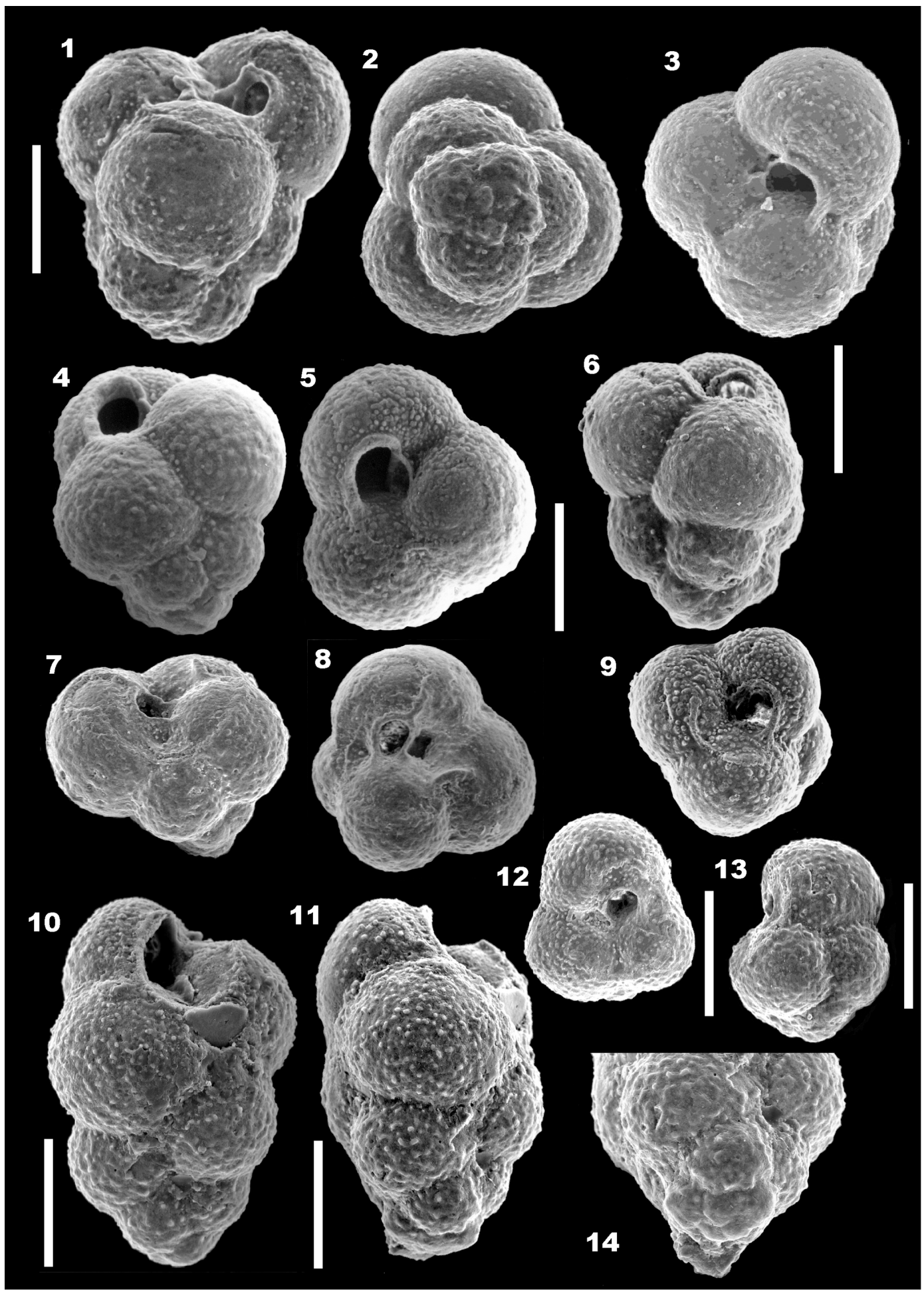

Figure 3. (1-14) Globuligerina bathoniana australiana n. ssp. 1-3. Paratype WAM 18.11/M2-17. (1) Side view; bulla broken off; (2) spiral (basal) view; (3) slightly oblique umbilical view, with two chambers in earlier whorls visible at right. (4, 5) Paratype WAM 18.12/M64-13; (4) side view; (5) umbilical view. (6,9) Holotype WAM 18.10/M10-21; (6) side view; (9) oblique umbilical view. Note the scar of a final, centrally positioned bulla. (7,8) WAM 18.16/M51-04. (7) side view; (8) umbilical view; final chamber broken off. (10, 11, 14) Paratype WAM 18.13/M73-09; (10) side view. The final chamber is broken off, and the apertural face of the second-last chamber is damaged; (11) side view with specimen rotated to show the very low trochospiral coil forming an almost flat base from certain angles. Contrast with the same area as seen in (10); (14) specimen at same angle of rotation as in (11), but tilted away from the viewer to show the initial whorl of four or five chambers, seen in side view in (11). (12, 13) Specimen WAM 18.15/M51-01; (12) umbilical view; (13) side view. All scale bars are 100 $\mu$ m, and all images on this figure are at the same magnification. All specimens are from sample BMR 95/DR7/8. 
to $0.29 \mathrm{~mm}$; the final chamber (and sometimes the last two chambers) is broken off in virtually all measured specimens so that the height/diameter (H/D) ratio would be greater than $1: 1$. Chambers hemispherical, arranged in a trochospiral coil of two to three whorls. All chambers (except the bulla) visible from the spiral side; only the three chambers of the final whorl visible from the umbilical side. Proloculus diameter 0.020 to $0.027 \mathrm{~mm}$; limits of proloculus difficult to see from exterior in some specimens due to secondary lamination. In some specimens the proloculus projects below the initial whorl and can be measured (Fig. 3: 2, 7, 14). The proloculus is usually surrounded by four to five hemispherical to elongated (in the direction of coiling) chambers in the first whorl, which forms a low trochospire, sometimes only slightly below the level of the proloculus. The sixth chamber usually increases markedly in size relative to earlier chambers (Fig. 3: 2) and marks the start of two later whorls of 3.5 to three chambers that form a much steeper coil. The third whorl (where preserved) always consists of three chambers (Fig. 3: 2, 4-5 (paratypes), Fig. 3: 6 (holotype), Fig. 3: 10 (paratype), Fig. 10: 1). The umbilicus varies in depth and width: either shallow or open to a depth of one whorl, with a central hollow, in specimens for which the three final chambers are coiled in a slightly more open coil (e.g. Fig. 3: 8; Fig. 10: 1, 6, 7). The area outside the aperture is lined with sharp tubercules with curved hook-like ends (Fig. 9: 5; Fig. 10: 9). The final chamber (or more than one) is always broken off, leaving a scar of attachment at the junction of the wall with older chambers, plus the inner lamella forming the lining of the chamber floor. The scar of attachment in some specimens suggests that the final chamber was a thin-walled inflated bulla, terminating the trochospiral coil by covering the central umbilical area and the aperture of the previous chamber (Fig. 3: 1, 9, 10-11). This bulla structure also has a lining of inner lamella covering its floor. No complete bulla has been found. The aperture consists of a medium to high, slightly asymmetrical arch, not semicircular, often sloping backwards up the face of the chamber. The aperture is variable in position, some specimens having it placed centrally on the final (preserved) chamber (Fig. 3: 3, 9, 12), while in others the position is slightly extraumbilical (Fig. 3: 5, 8). Such variations are connected to the tightness of coiling: in some specimens there is an open triangular umbilical hollow, one chamber deep, as a separate space (Fig. 3: 8; Fig. 9: 2, 3; Fig. 10: 1, 6,7). In other specimens the last three chambers are in close contact so that there is only a shallow depressed area (or the apertural opening) at their junction (Fig. 3: 9, 12). In the tightly coiled specimens the aperture lies close to the centre of the specimen, whilst in the looser coiled, the aperture on the last chamber is naturally more offset towards the outside of the specimen (Fig. 3: 8). The aperture is bordered by a thickened asymmetrical lip (Fig. 3: 1, 5, 8, 9). At the end bordering the umbilicus, the margin of the aperture forms a nearly straight vertical wall connecting with the chamber surface below. Successive apertures rotate at angles of $120^{\circ}$ around the umbilicus (Fig 3: 5; Fig. 9: 5; Fig. 10: 1). During the construction of the next chamber the apertural lip is extended into a portico-like structure by the deposition of inner lamella forming the floor of the next chamber (Fig. 10: 1).

\section{Wall structure}

Each chamber wall is initially bilamellar; all older chambers have additional layers of secondary lamination. The wall consists of (1) perforate inner lamella approximately $1 \mu \mathrm{m}$ thick, completely covering each chamber including its floor (Fig. 8: 13); (2) outer lamella, perforate and with very low pseudomuricae on the outer surface (Fig. 8: 13); (3) secondary lamination covering the entire exterior surface of the test with each chamber addition (Fig. 8: 11-13). Ultimately all depressions in the surface of the proloculus and earliest chambers are infilled by secondary lamination (Fig. 3: 14). External wall "ornament" of pseudomuricae varies from chamber to chamber as part of the growth of the test, and pseudomuricae progressively increase in size with secondary lamination. It is therefore essential to specify which chamber close-up photographs of surface ornament are from. Ornament in the umbilicus consists of sharp pointed tubercules (Fig. 9: 5; Fig. 10: 7-10). They are present in many specimens in the umbilicus and in front of each aperture (Fig. 10: $1,5,7-10)$. Within newly formed chambers, pseudomuricae are covered by inner lamella, and so are smoothed over with the addition of each subsequent chamber, but are still visible as lumps in the chamber floor (Fig. 6: 4). Most specimens show broken remnants of a thin-walled bulla (Fig. 3: 1, 7, 9).

\section{Wall composition}

Raman spectroscopy results on G. bathoniana australiana from the well-preserved sample BMR 95/DR7/8, performed by Aleksey Sadekov of the University of Western Australia, indicate that the wall composition of this species is aragonite, with a high organic content. The methodology of measurement is described in DeCarlo et al. (2019).

\section{Occurrence and age}

Dredge samples BMR 95/DR7/8 and BMR 96/DR28/16; early Bajocian based primarily on nannoplankton (see Sect. 3).

\section{Dimensions}

Refer to Table 1.

\section{Remarks}

This form appears to be a subspecies of Globuligerina bathoniana (Pazdrowa). The differences from G. bathoniana s.s. are described as follows. The presence of only three (very 
Table 1. Dimensions and number of chambers in each whorl of selected imaged specimens. Specimen numbers preceded by WAM are figured in this paper and lodged with the Western Australian Museum; /M indicates the same specimen with the imaging reference number. Specimens preceded only by M image numbers are shown in the Supplement. Specimens in bold type are the holotypes. $p$ : proloculus; $b$ : bulla; where "no image" is noted, no image at the appropriate orientation for dimensions is available.

\begin{tabular}{|c|c|c|c|c|c|c|c|}
\hline Specimen no. & $\begin{array}{l}\text { Height } \\
(\mathrm{mm})\end{array}$ & $\begin{array}{r}\text { Max diam } \\
(\mathrm{mm})\end{array}$ & $\begin{array}{r}\text { No. of } \\
\text { chambers }\end{array}$ & $\begin{array}{l}\text { First whorl } \\
\text { chambers }\end{array}$ & $\begin{array}{r}\text { Second whorl } \\
\text { chambers }\end{array}$ & $\begin{array}{r}\text { Third whorl } \\
\text { chambers }\end{array}$ & Bulla \\
\hline \multicolumn{8}{|c|}{ Globuligerina bathoniana australiana n. ssp. } \\
\hline WAM 18.10/M10-21 & 0.215 & 0.170 & $p+11+b$ & $4 ?$ & $3-4$ & 3 & yes \\
\hline WAM 18.11/M2-17 & 0.235 & 0.218 & $p+11+b$ & 5 & 3 & 3 & yes \\
\hline WAM 18.12/M64-13 & 0.228 & 0.196 & $p+7+b$ & 4 & 3 & 0 & yes \\
\hline WAM 18.13/M73-09 & 0.287 & 0.187 & $p+11$ & 5 & 3 & 3 & broken \\
\hline WAM 18.14/M10-36 & 0.242 & 0.218 & $?$ & no image & 4 & 3 & yes \\
\hline WAM 18.15/M51-01 & 0.164 & 0.152 & $p+7 ?+b$ & $4 ?$ & 3 & 0 & yes \\
\hline WAM 18.16/M51-04 & $>0.185$ & 0.184 & $p+7.5 ?+b$ & $4 ?$ & 3.5 & 0 & yes \\
\hline WAM 18.17/M51-06 & 0.127 & 0.115 & $p+9$ & 4 & 3 & 2 missing & broken \\
\hline WAM 18.18/M55-28 & 0.132 & 0.162 & no image & $?$ & 3 & 0 & $?$ \\
\hline WAM 18.19/M73-10 & 0.151 & 0.154 & $p+12 ?$ & 5 & 4 & 3 broken & $?$ \\
\hline WAM 18.20/M52-09 & 0.110 & 0.110 & $p+12 ?$ & $4-5$ & 4 & 3 broken & broken \\
\hline M2-16 & 0.188 & 0.174 & $p+>9$ & 5 & 3 & 1 broken & broken \\
\hline M10-30 & $>0.180$ & 0.159 & $p+>10$ & $4 ?$ & 3 & 3 broken & broken \\
\hline M86-19 & 0.226 & 0.223 & $p+>7$ & 4 & 3 & broken & broken \\
\hline \multicolumn{8}{|c|}{ Globuligerina altissapertura $\mathrm{n} . \mathrm{sp}$. } \\
\hline WAM 18.3/M10-23 & 0.205 & 0.179 & $p+6 ?$ & $3-4$ & 3 & 0 & yes \\
\hline WAM 18.4/M55-27 & 0.135 & 0.132 & $p+6-7$ & $>4$ & 3 & 0 & yes \\
\hline WAM 18.5/M73-14 & no image & 0.129 & $?$ & $?$ & 3 & 0 & yes \\
\hline WAM 18.6/M86-6 & 0.223 & 0.209 & no image & $? 4$ & 3 & 0 & yes \\
\hline WAM 18.7/M10-22 & 0.186 & 0.179 & no image & no image & 3 & 0 & yes \\
\hline WAM 18.8/M4-59 & $>0.110$ & 0.138 & $p+8$ & 5 & 3 & broken & broken \\
\hline WAM 18.9/M51-02 & 0.164 & 0.200 & $p+7 ?+b$ & $4 ?$ & 3 & 0 & yes \\
\hline M10-24 & 0.172 & 0.185 & $p+7+b$ & 4 & 3 & 0 & yes \\
\hline M32-27 & 0.165 & 0.176 & $p+>8$ & 5 & 3 & broken & $?$ \\
\hline WAM 19.1/M5-07 & no image & 0.184 & $p+9+b$ & $4 ?$ & 3 & 2 & yes \\
\hline \multicolumn{8}{|c|}{ Mermaidogerina loopae n. gen. n. sp. } \\
\hline WAM 18.22/M52-01 & 0.133 & 0.138 & $p+6+b$ & 3 & 3 & 0 & yes \\
\hline WAM 18.23/M11-35 & 0.125 & 0.137 & $p+6+b$ & 3 & 3 & 0 & yes \\
\hline WAM 18.24/M51-03 & 0.145 & 0.145 & $p+6 ?+b$ & $3 ?$ & 3 & 0 & yes \\
\hline WAM 18.25/M52-04 & no image & 0.110 & $p+6$ & 3 & 3 & broken & broken \\
\hline WAM 18.26/M101-8 & no image & 0.172 & $p+8$ & 3 & 3 & 1 & no image \\
\hline
\end{tabular}

rarely, 3.5) chambers in the final whorl, the presence of internal lamellae flooring the chambers, and the medium- to high-arched aperture suggest that this is a distinct subspecies within the wide and variable concept of G. bathoniana as described by Pazdrowa (1969), Hart et al. (2012), and Gradstein et al. (2017a). This subspecies has a height that exceeds the diameter (except where later chambers are broken off). In $G$. bathoniana australiana the proloculus is surrounded by four, rarely five, chambers, with three to four chambers in the second whorl and three in the third whorl. The third whorl in the Australian form (where preserved) always consists of three chambers (Fig. 3: 1-2, 4-5, 6, 9, 10). Pazdrowa (1969) described $G$. bathoniana as having three to four chambers in the final whorl; the holotype has four. Only specimens DG-5 and possibly DG-6 (Pazdrowa, 1969, fig. 5a-f, 6) are drawn with three chambers in the final whorl, and there is no indication of whether these are "type" specimens or an extreme variant. The paratypes all have four chambers in the final whorl according to Hart et al. (2012) and Gradstein et al. (2017a). The latter authors state that "Our observations do confirm that $G$. bathoniana does not have 3 chambers in the last whorl; hence, this might be characteristic to assign specimens to $G$. dagestanica". However, the holotype of G. dagestanica "has 4 and not 3 chambers in the last whorl" (Gradstein et al. 2017a). G. dagestanica also has a somewhat triangular shape to the test when seen in outline, whereas G. bathoni- 
ana australiana has strongly inflated chambers, deep sutures, and a petaloid outline in umbilical or spiral view (Fig. 3: 2). A clear difference from $G$. bathoniana s.s. is that all of the Australian specimens have three chambers in the third whorl. If one takes an assemblage view of species (as does Gradstein et al. 2017a), then the geographically remote Australian assemblage has shifted its coiling mode to a three-chambered form and does not have the largely four-chambered coiling of the European form. The present form is similar to G. bathoniana gigantea Wernli and Görög (1999), in that only three chambers make up the later whorls, but differs from it by being smaller (height 0.11 to $0.28 \mathrm{~mm}$ versus 0.28 to $0.32 \mathrm{~mm}$ ), by having a more conical tapering test shape with strongly inflated chambers and deeper sutures, whereas gigantea has more tightly appressed chambers, and by often having the proloculus prominent in side view, whereas the profile of the base of gigantea is more rounded. Both these subspecies include specimens much larger than G. bathoniana s.s. according to fig. 12 of Pazdrowa (1969), which shows a maximum height of $0.195 \mathrm{~mm}$ and a maximum diameter of $0.185 \mathrm{~mm}$. From the high-spired Globigerina (Conoglobigerina) avarica Morozova 1961, G. bathoniana australiana differs in being much less triangular in outline and in having inflated hemispherical chambers and well-defined sutures. It is felt that these differences justify the erection of this new subspecies, Globuligerina bathoniana australiana.

\section{Comparison of age range}

Pazdrowa's specimens of Globuligerina bathoniana s.s. were from the middle Bathonian of Poland, and the species is reported to range from the Bajocian to the Kimmeridgian. This Australian material is very early in the species range (earliest Bajocian). Globuligerina bathoniana gigantea Wernli and Görög is also recorded from the Bajocian.

\section{Globuligerina altissapertura $\mathrm{n} . \mathrm{sp}$.}

Fig. 4: 1-12; Fig. 6: 1-3; Fig. 7: 5-6; Fig. 8: 1-8; Fig. 9: $1-3$.

\section{Holotype}

Specimen WAM 18.3/M10-23 (Fig. 4: 9, 12).

\section{Paratypes}

Specimens WAM 18.4/M55-27 (Fig. 4: 7-8, 10-11); WAM 18.5/M73-14 (Fig. 4: 2-3; Fig. 7: 5-6); WAM 18.6/M86-6 (Fig. 4: 4-6); WAM 18.7/M10-22 (Fig. 4: 1).

\section{Type locality}

Sample BMR 95/DR7/8, dredged at a water depth of 4530 to $3900 \mathrm{~m}$ on the northeastern wall of Mermaid Canyon, offshore of northwestern Australia; the dredge haul starting at $16^{\circ} 18.9^{\prime} \mathrm{S}, 118^{\circ} 22.2^{\prime} \mathrm{E}$ and ending at $16^{\circ} 18.2^{\prime} \mathrm{S}$, $118^{\circ} 24.3^{\prime} \mathrm{E}$.

\section{Derivation of species name}

Describing the high aperture.

\section{Diagnosis}

Test calcareous, a medium-high globigerinid trochospire, rapidly expanding, with an $\mathrm{H} / \mathrm{D}$ ratio of approximately $1: 1$. Coil of usually two whorls, the final whorl containing three to rarely 3.5 spherical chambers. Aperture a very high arch, almost loop-shaped or virguline, with a prominent lip; aperture umbilical or slightly extraumbilical in position. Wall structure microperforate, with prominent pseudomuricae, showing a sequence of development on different chambers by secondary lamination.

\section{Description}

Trochospirally coiled test with a rapidly expanding spire of usually two whorls, the H/D ratio approximating $1: 1$. The proloculus on the holotype and most specimens is prominent at the base, visible below four to five chambers in the first whorl and three in the subsequent whorl (Fig. 4: 9). One paratype (WAM 18.4/M55-27) has a flattened first whorl but this is not typical (Fig. 4: 11). Heavy secondary lamination often obscures the chambers in the first whorl. The second and usually final whorl consists of three hemispherical chambers. The sutures are depressed, their shape at depth modified by wall ornament. The aperture is umbilical, a narrow, very high arch, about $10 \mu \mathrm{m}$ wide, asymmetrical, almost loopshaped, rising one-third to halfway up the face of the final chamber. The aperture is rimmed by a narrow lip ornamented by tubercules from the top of the arch down to the outer margin (Fig. 4: 4, 6, 12). The inner margin of the apertural lip (i.e. the margin closest to the axis of coiling) is smooth and turns outwards in a curved, plate-like extension of the lip, forming a buttress-like structure where the lip attaches to the previous whorl (Fig. 4: 1, 4, 6, 9; Fig. 6: 1). The final chamber or bulla is broken away in almost all specimens. Paratype WAM 18.6/M86-6 has the final chamber broken off but a well-preserved aperture on the penultimate chamber (Fig. 4: 4-6). Paratype WAM 18.5/M73-14 appears to have had a terminal bulla, as the scar of attachment occupies a central position above the last three chambers (Fig. 4: 2; Fig. 7: 5). A small remnant of very thin, single-layered wall is attached to the apertural margin of the previous chamber (Fig. 4: 3); this remnant (arrowed) is interpreted to be part of the bulla.

\section{Wall structure}

Each chamber wall consists of inner lamella approximately $2 \mu \mathrm{m}$ thick, coating the floor of the chamber and the new 


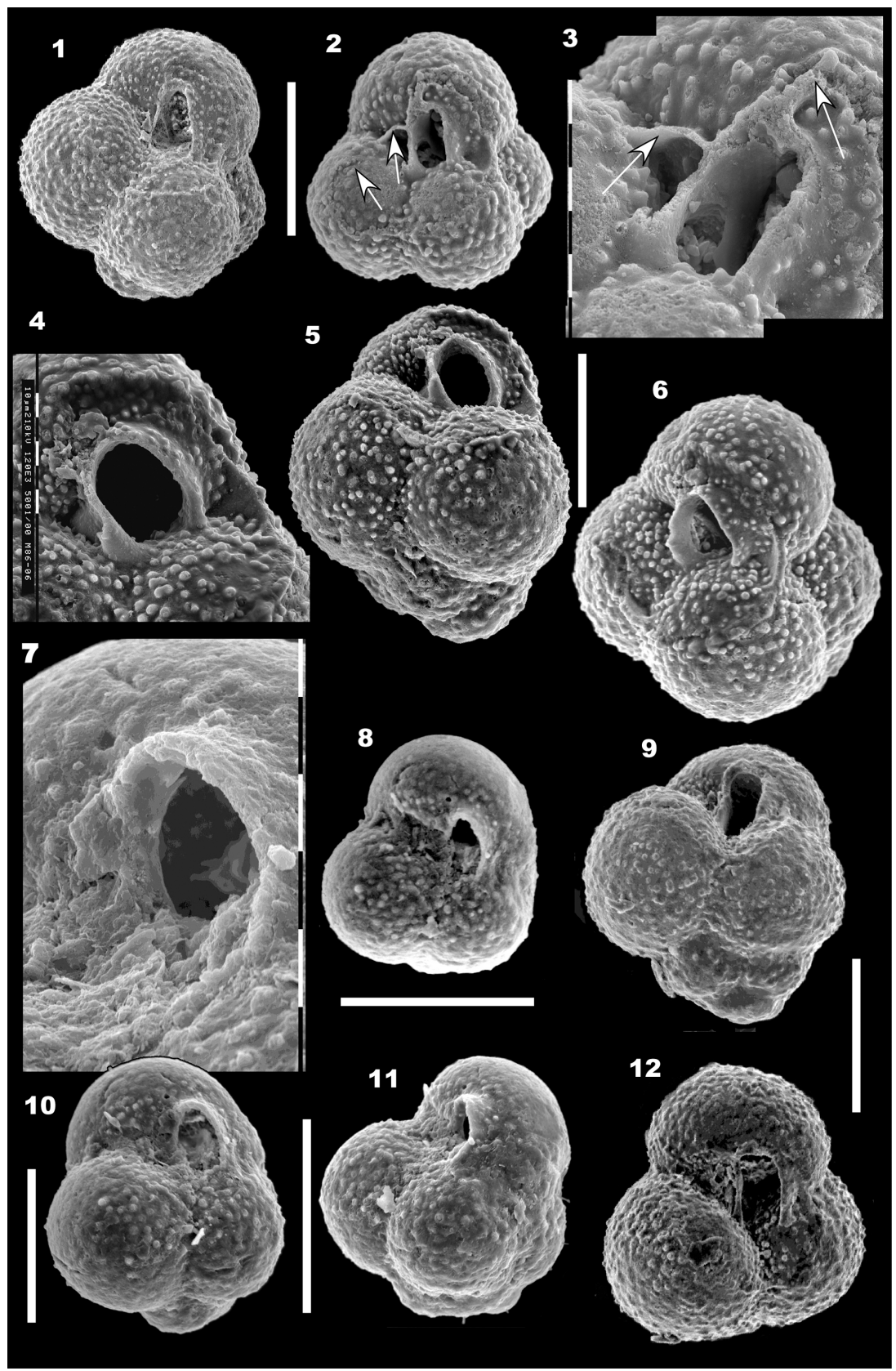

Figure 4. (1-12) Globuligerina altissapertura n. sp. 1, Paratype WAM 18.7/M10-22, oblique umbilical view. Note the scar of a terminal bulla, now broken off. Scale bar for (1) and (2): $100 \mu \mathrm{m}$. (2-3) Paratype WAM 18.5/M73-14; (2) umbilical view to show the narrow, higharched aperture. The terminal bulla is broken off but visible as broken walls and a scar on the last three chambers (arrowed). (3) Detail of the aperture and a small section of the thin-walled broken bulla (arrowed). Composite photomosaic, each division of scale at left is 10 $\mu$ m. (4-6) Paratype WAM 18.6/M86-6 from sample BMR 96/DR28/16. (4) Detail of the aperture, showing the high tilted arch, prominent lip and the outwards turning of the lip to form a small hook-like plate on the umbilical side of the aperture. Each small scale bar is $10 \mu \mathrm{m}$. (5) Side view; a final bulla is broken off. (6) Oblique umbilical view, showing the very prominent lip around the aperture in partial side view. The scale bar between (5) and (6) is $100 \mu \mathrm{m}$. (7, 8, 10-11) Paratype WAM 18.4/M55-27. (7) Detail of the aperture; apertural lip is broken on the umbilical side. Each division of scale bar: $10 \mu \mathrm{m}$. (8) Umbilical view, showing the narrow high tilted aperture and the three chambers in the final whorl, plus the faint scar of a possible broken-off bulla covering the umbilical surface. Scale bar below (8): $100 \mu \mathrm{m}$. (10) Oblique umbilical view, tilted away from viewer relative to (8) to show apertural shape. (11) Side view, rotated to show the prominence of the projecting apertural lip on the final chamber. Note the almost flat initial whorl at the base; this is unusual. Scale bar for (10) and (11): 100 $\mu$ m. (9, 12) Holotype WAM 18.3/M10-23. (9) Side view with proloculus clearly visible at the base and secondary lamination infilling the wall ornament on the early chambers. (12) Umbilical view. The high loop-shaped aperture is almost centrally located above the suture of the second-last and third-last chambers. Scale bar between (9) and (12): $100 \mu \mathrm{m}$. Specimens from sample BMR 95/DR7/8 unless stated otherwise. 
wall, and microperforate outer lamella approximately 3$4 \mu \mathrm{m}$ thick (Fig. 6: 3; Fig. 9: 3). A gap between these lamellae has been suggested to consist of an organic matrix which likely corresponds to the primary organic membrane (Aleksey Sadekov, personal communication, 2019). A chamber-by-chamber photographic analysis shows that on the youngest chamber, pseudomuricae are scattered and low, and the chamber surface is microperforate with pores $<1 \mu \mathrm{m}$ in diameter scattered between the pseudomuricae (Fig. 8: 12 ). Older chambers acquire progressively larger pseudomuricae due to secondary lamination (Fig. 8: 4-5), and pseudomuricae become joined by ridges due to this process (Fig. 8: 6-8). These ridges on the earliest chambers change the pattern of ornament into a ridged one rather than a pustulose ornament (it is stressed that this ridge infilling between pseudomuricae affects only older chambers). The pseudomuricae enlarged by secondary lamination finally become buried in the wall of the earliest chambers as later chambers are added (Fig. 4: 9, 11). Inner lamella is also deposited as an apron in front of the aperture. It covers the floor of each successive chamber, coating the pseudomuricae of the previous chamber surface (Fig. 6: 3; Fig. 9: 3). In some specimens this inner lamella floor coating appears imperforate (Fig. 6: 3), whilst in others pores penetrate this surface (Fig. 9: 3). Pores are initially confined to valleys between pseudomuricae (Fig. 7: 6). Slightly sinuous pores of extreme thinness $(<0.5 \mu \mathrm{m})$ penetrate the chamber walls through both the outer and inner lamellae at a spacing of 1 to $3 \mu \mathrm{m}$ (Fig. 6: 3). The pores do not appear to end in pore pits but have a near-constant thickness through the wall. On the outer surface of the test, some pores are blocked by secondary lamination (Fig. 6: 3). Pseudomuricae are usually solid at the outer surface when first formed (Fig. 7: 6), but later some acquire a central pore or are penetrated by pores after secondary lamination. Some specimens have curved and very sharp hooks in the umbilicus and in front of each aperture (Fig. 6: 1).

\section{Wall composition}

Raman spectroscopy results on G. altissapertura from sample BMR 95/DR7/8, performed by Aleksey Sadekov of the University of Western Australia, indicate that the wall composition of this species is aragonite, with a high organic content.

\section{Dimensions}

Refer to Table 1.

\section{Occurrence and age}

Dredge samples BMR 95/DR7/8 and BMR 96/DR28/16; early Bajocian based on nannoplankton (see Sect. 3).

\section{Remarks}

This form is distinguished from Globuligerina bathoniana australiana by the narrow very high aperture and the rapidly expanding trochoid test usually of two whorls. Although it has been indicated in the literature (Gradstein et al., 2017a) that the aperture is a variable and transitional feature in $G$. bathoniana, in photographed specimens of the present material it has been possible to consistently assign specimens to either G. altissapertura n. sp. or to G. bathoniana australiana n. ssp. using the aperture. Pazdrowa (1969) in her original description of Globuligerina bathoniana stated that high and narrow apertures were "rare", not "normal". In her material "The presence of passage forms does not permit the establishment of separate systematic units" (Pazdrowa, 1969 , p. 51), whereas in the present material, the rare narrow apertures become frequent in the population, and the form can be distinguished from $G$. bathoniana australiana $\mathrm{n}$. ssp. G. altissapertura, with its rapidly expanding medium-high spire, is not conspecific with the low-spired G. oxfordiana (Grigelis), which was recently redescribed (Grigelis, 2016). Statements that $G$. oxfordiana includes forms with only three chambers in the last whorl are not supported by type specimens or by illustrations of topotype material (see Grigelis, 2016, and Gradstein et al., 2017a). Due to the much higher spire of $G$. altissapertura and fewer chambers in the last whorl (three versus four in G. oxfordiana), as well as the very high aperture, it seems necessary to give these mediumhigh-spired Australian forms with a high-arched, "virgulineshaped" aperture a new name.

\section{Mermaidogerina new genus}

Type species

Mermaidogerina loopae n. gen. n. sp., here designated.

\section{Derivation of genus name}

From the type locality, Mermaid Canyon, North West Shelf, Western Australia.

\section{Diagnosis}

Trochospiral, entirely triserially coiled, smooth-walled to very low pustulose planktonic taxon, with a high, loopshaped aperture, extraumbilical, excentrically placed near the outer edge of the final chamber, and bounded by a thick lip.

\section{Type locality}

Sample BMR 95/DR7/8, dredged at a water depth of 4530 to $3900 \mathrm{~m}$ on the northeastern wall of Mermaid Canyon, 


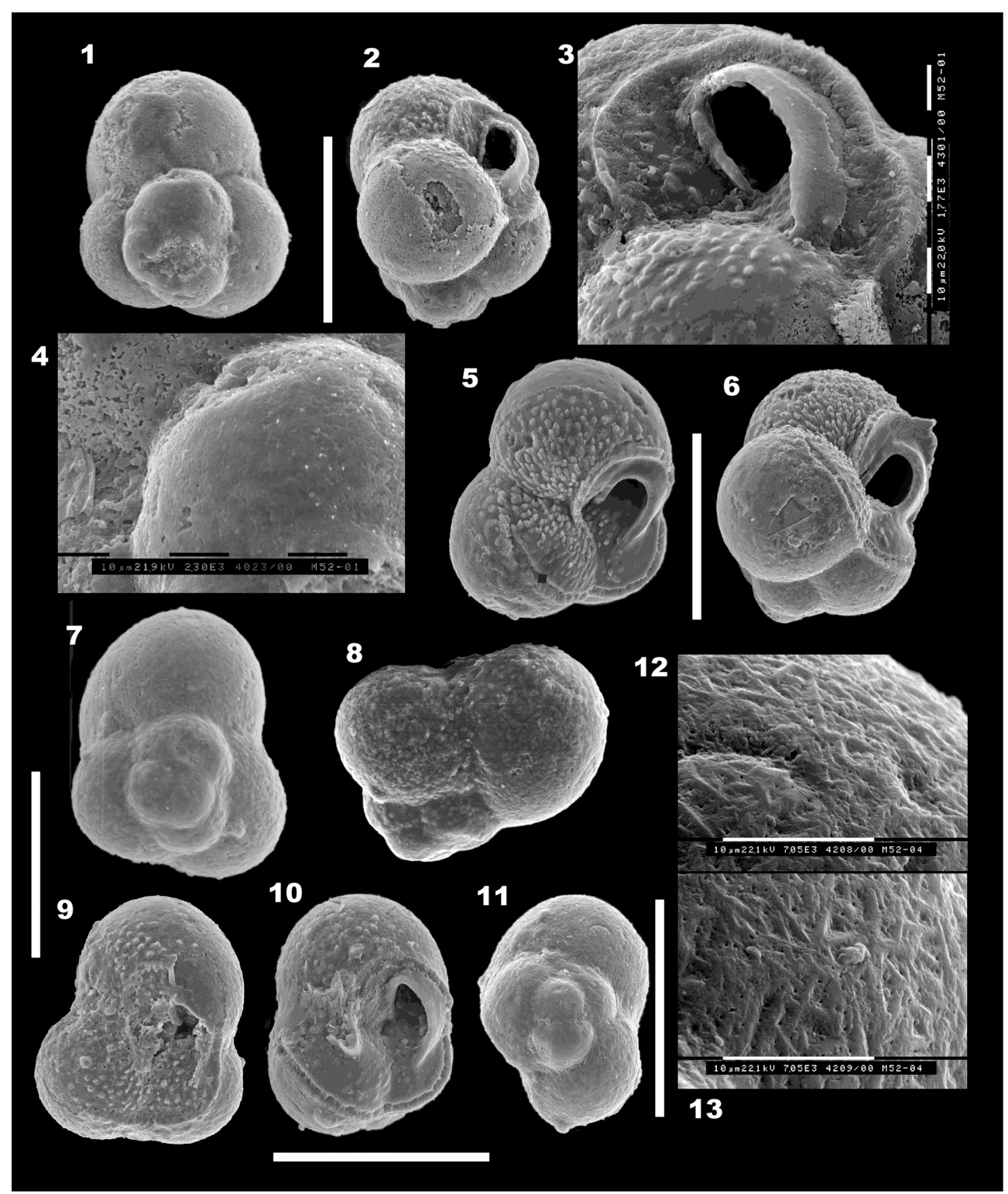

Figure 5. (1-13) Mermaidogerina loopae n. gen. n. sp. Scale bars are $100 \mu \mathrm{m}$ unless shown otherwise for individual figures. (1-4) Holotype WAM 18.22/M52-01; (1) spiral view; (2) side view; (3) detail of the asymmetrical loop-shaped aperture, turned to face the umbilicus, with the thickened lip on the peripheral margin extending forward into the broken final chamber. Each division of the scale bar is $10 \mu \mathrm{m}$ for (3) and (4). (4) Detail of the smooth surface of the fourth chamber and part of the etched final chamber, as seen in (1). (5-6) Paratype WAM 18.24/M51-03; (5) umbilical view of the triserial test, showing the broken final chamber at lower right and the scar of the thin-walled final bulla (at top and lower left), with tooth-like tubercules within the area of the bulla. (6) Side view, showing the asymmetrical loop of the aperture and smooth surface, lacking pseudomuricae, of the early chambers. The broken final chamber and the area covered by a thin-walled bulla are indicated by the faint scar of those walls. The prominent tubercules are virtually confined to the area in front of the aperture and within the final bulla. (7-9) Paratype WAM 18.23/M11-35; (7) spiral view showing porous surface with rare low pseudomuricae on the earlier chambers only. (8) Profile view, showing the raised, well-defined proloculus and initial whorl. (9) Umbilical view, with the final chamber or bulla broken off. Tubercules are well developed inside the broken chamber area. The aperture is damaged but part of the lip is visible. The scale bar at left is $100 \mu \mathrm{m}$ for (7), (8) and (9). (10-13) Paratype WAM 18.25/M52-04; (10) oblique umbilical-side view, showing shape of aperture, thick lip and broken final chamber. Note that the final aperture on the broken chamber was situated at the left side in an extraumbilical position. (11) Spiral (basal) view to show the proloculus and triserial coiling. The final chamber is broken away at lower left; it originally completed the second whorl. $(\mathbf{1 2}, \mathbf{1 3})$ Two nearly contiguous areas on the surface of the second-last chamber (at upper right in 11). Note the "herring-bone" texture of interlocking triangular ridges, which are interspersed with pores. Note the absence of pseudomuricae on the porous wall. Scale bars on (12) and (13): $10 \mu \mathrm{m}$; original magnification is $7050 \times$. All specimens are from sample BMR 95/DR7/8. 


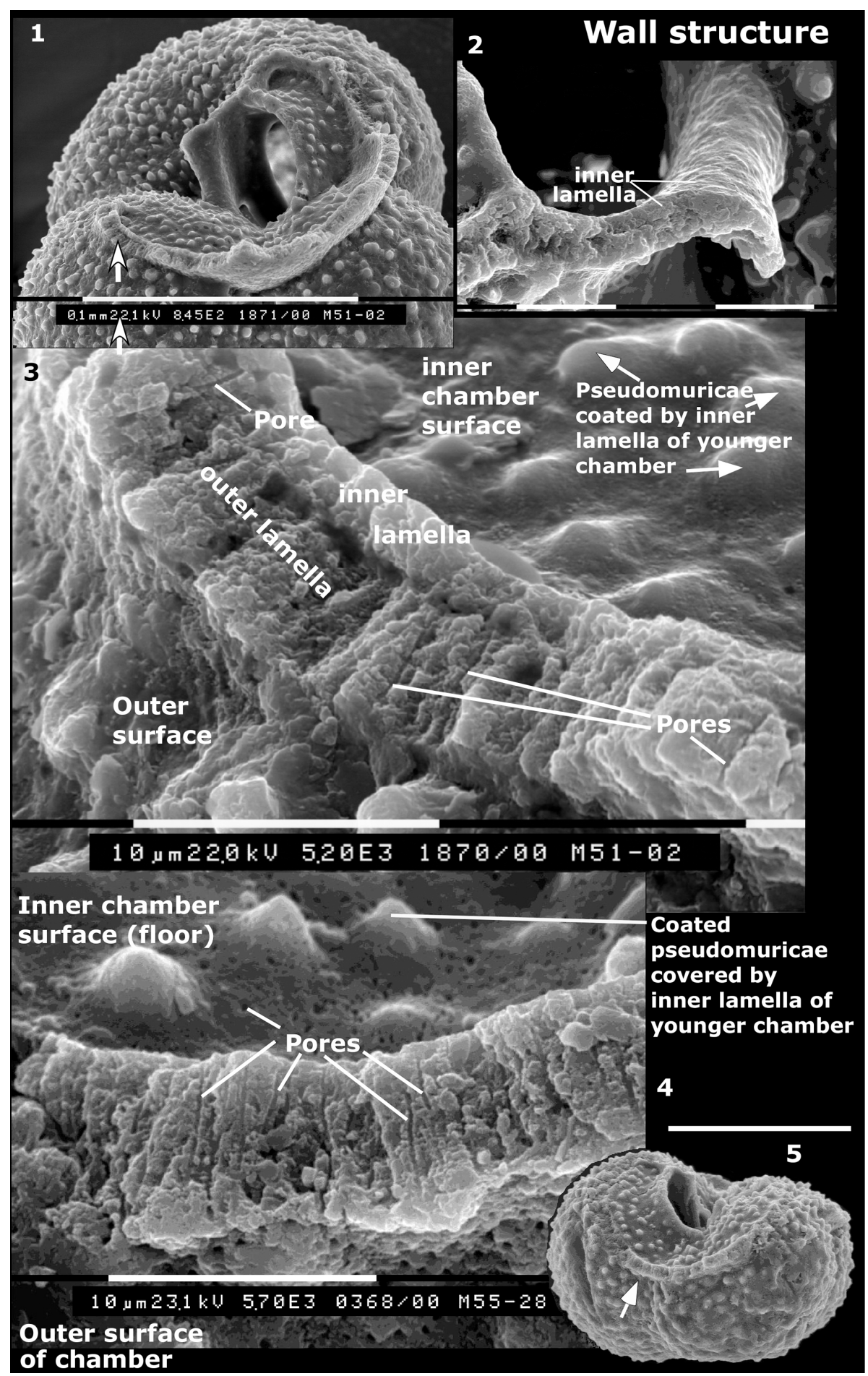

Figure 6. Wall structure (1-3) Globuligerina altissapertura n. sp., specimen WAM 18.9/M51-02; (1) side view of later chambers to show broken wall of final chamber and base of broken apertural lip of final chamber; scale bar: $100 \mu \mathrm{m}$; (2) apertural lip of final chamber, seen from above. Note the inner lamella that appears to thicken as it bends into the curved edge of the lip. Each scale bar: $10 \mu \mathrm{m}$. (3) Broken wall of the final chamber (location arrowed in 1) to show inner lamella coating the floor of the chamber, outer lamella and thin pores which appear to pass through both. Each scale bar: $10 \mu \mathrm{m}$. (4-5) Globuligerina bathoniana australiana n. ssp., specimen WAM 18.18/M55-28; (4) detail of broken wall, showing well-developed pores and porous inner surface of chamber (at top) and outer surface of wall (at bottom). Scale bar for (4): $10 \mu \mathrm{m}$. (5) Whole specimen, side view to show wall location (lower arrow). Scale bar for (5) (above 5): $100 \mu \mathrm{m}$. 
offshore of northwestern Australia; the dredge haul starting at $16^{\circ} 18.9^{\prime} \mathrm{S}, 118^{\circ} 22.2^{\prime} \mathrm{E}$ and ending at $16^{\circ} 18.2^{\prime} \mathrm{S}$, $118^{\circ} 24.3^{\prime} \mathrm{E}$.

Age

Earliest Bajocian based mainly on nannoplankton (see Sect. 3).

Mermaidogerina loopae n. gen. n. sp.

Fig. 5: 1-13; Fig. 7: 1-4; Fig. 11: 1-4.

Derivation of species name

From the high, loop-shaped aperture.

Holotype

WAM 18.22/M52-01 (Fig. 5: 1-4; Fig. 11: 1).

\section{Paratypes}

WAM 18.24/M51-03 (Fig. 5: 5-6); WAM 18.23/M11-35 (Fig. 5: 7-9; Fig. 7: 3-4; Fig. 11: 3); WAM 18.25/M52-04 (Fig. 5: 10-13; Fig. 11: 2); WAM 18.26/M101-08 (Fig. 7: 1-2; Fig. 11: 4).

Material

10 specimens photographed; another 14 not photographed.

Type locality

As for the genus.

\section{Diagnosis}

Smooth-walled to very low pustulose-walled, entirely triserially coiled trochospiral form, with a high, loop-shaped aperture, extraumbilical, excentrically placed near the outer edge of the final chamber, and bounded by a thick lip.

\section{Description}

Test calcareous, a medium trochospire, triserially coiled, composed of hemispherical chambers arranged at approximately $120^{\circ}$ to each other (Fig. 5: 1, 7, 11; Fig. 7: 1, 3; Fig. 11). Test width expanding rapidly between the first and second whorls. Initial chambers clearly visible, with the proloculus well defined and projecting at the base of the test. Sutures in both spiral and umbilical views curved and depressed; peripheral outline lobulate. The holotype has the last chamber missing, plus the broken trace of a large terminal bulla, which appears to have covered the top half of the last three chambers (Fig. 5: 2). Most specimens photographed on the umbilical side have the scar of a bulla, now broken off (Fig. 5: 5). The aperture is a high loop-shaped asymmetrical opening, virguline in shape, extraumbilical, situated close to the outer edge of the chamber, facing the umbilicus (Fig. 5: 2-3, 5-6, 10). The aperture is rimmed by a smooth lip throughout, which on the peripheral side thickens and becomes very wide. In several specimens including the holotype, the thickened lip has the appearance of inner lamella that has "spilled out" from the interior of the chamber (Fig. 5: $3,5,10)$.

\section{Wall structure}

Wall brown in colour, smooth, shiny when seen under the binocular microscope, microperforate, with pores less than $0.5 \mu \mathrm{m}$ in diameter, widely and evenly scattered across chamber surfaces. Most specimens have virtually no development of tubercules or pseudomuricae except within the area formerly covered by the bulla, where they are prominent and elongated (Fig. 5: 2-3, 5-6, 9, 10). This suggests that diagenesis is not responsible for the smooth outer wall, since that process has not impacted the area of the broken bulla. Paratype WAM 18.23/M11-35 has low tubercules on the fifth and sixth chambers and scattered small tubercules on earlier chambers (Fig. 5: 8-9). The wall appears to consist of inner and smooth outer lamellae, with little additional secondary lamination (Fig. 7: 1-4). The wall is smooth in some specimens, etched in others. The holotype in its last two preserved chambers shows patchy dissolution (Fig. 5: 1-2), but earlier chambers are smooth with scattered pores (Fig. 5: 4). One paratype, WAM 18.25/M52-04, has a wall surface that appears smooth at low SEM magnification and under the binocular microscope (Fig. 5: 11), but at $7000 \times$ it is seen to consist of a reticulate maze of low interlocking $\mathrm{V}$-shaped ridges (Fig. 5: 12-13) with numerous fine pores between the ridges. These would not be expected if the wall had been recrystallised.

\section{Wall composition}

In specimens from sample BMR 95/DR7/8, the wall has been indicated to be aragonite, with a high organic content, according to Raman spectroscopy by Aleksey Sadekov.

\section{Dimensions}

Refer to Table 1. 


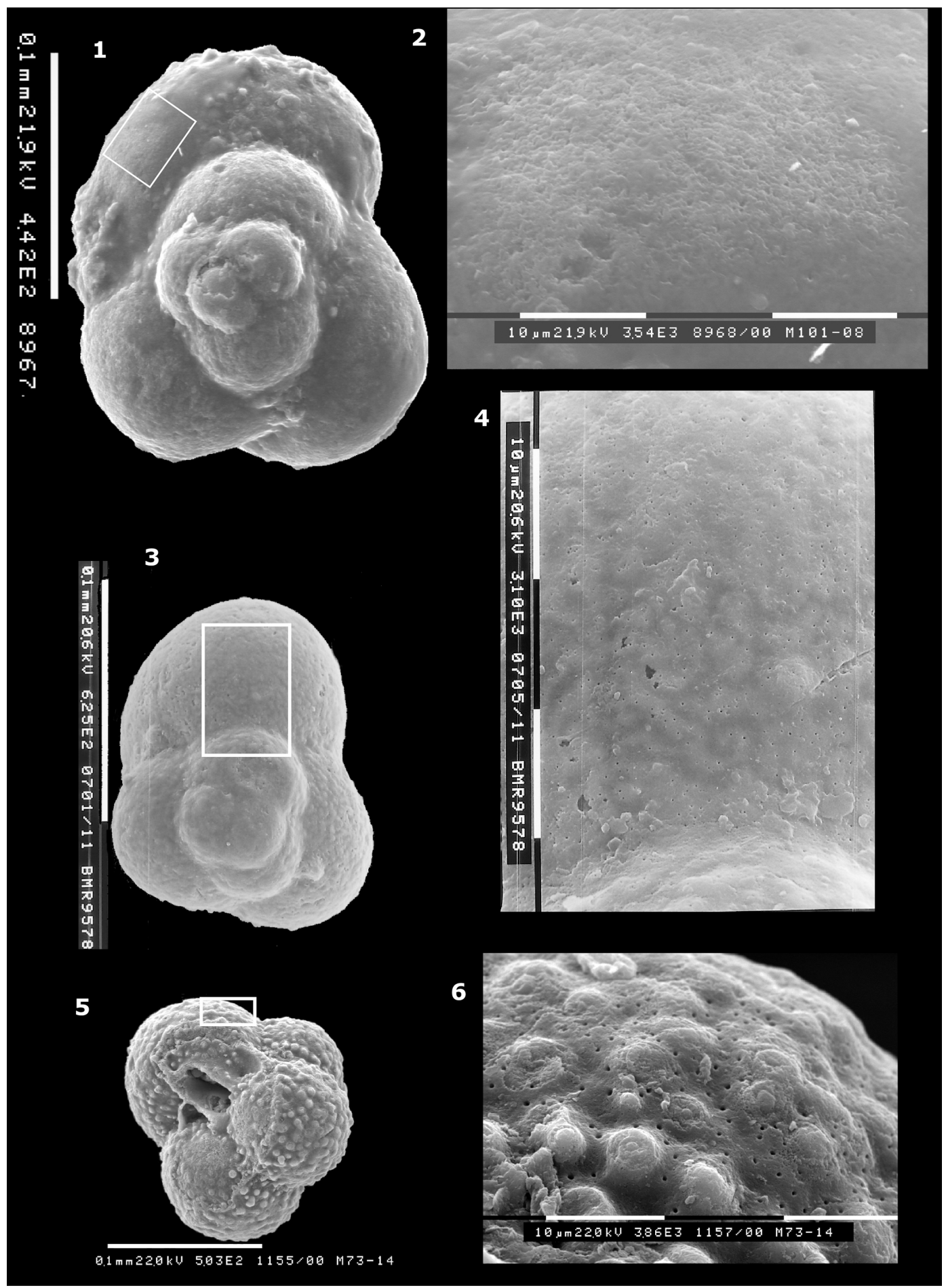

Figure 7. Contrasting wall structures, outer surface. (1-2) Mermaidogerina loopae n. gen. n. sp., Paratype WAM 18.26/M101-08; (1) spiral view, showing smooth-walled test, except for scattered pseudomuricae on the final (ninth) chamber. Scale bar: 100 $\mu$ m. (2) Part of surface of final chamber within box in (1); showing smooth, slightly etched surface but lacking tubercules or pseudomuricae. Each scale bar at base: $10 \mu \mathrm{m}$. Specimen from sample BMR 96/DR28/16. (3-4) Mermaidogerina loopae n. gen. n. sp., WAM 18.23/M11-35. (3) Spiral view of triserial test; (4) detailed view of wall of final chamber in box in (7: 3), showing smooth surface, finely perforate on final chamber. Earlier whorl at bottom of image shows very low raised areas. (5-6) Globuligerina altissapertura n. sp., Paratype WAM 18.5/M73-14 (see also Fig. 4: 2-3); (5) whole specimen; note the scar of the final bulla that is broken off. Scale bar: $100 \mu \mathrm{m}$. (6) Well-preserved pseudomuricae and pore structure on the last-preserved chamber (area in box in (5)). The layer of secondary lamination on these pseudomuricae is presumably associated with formation of the terminal bulla. Each scale bar: $10 \mu \mathrm{m}$. (3-6) Specimens from sample BMR 95/DR7/8. 


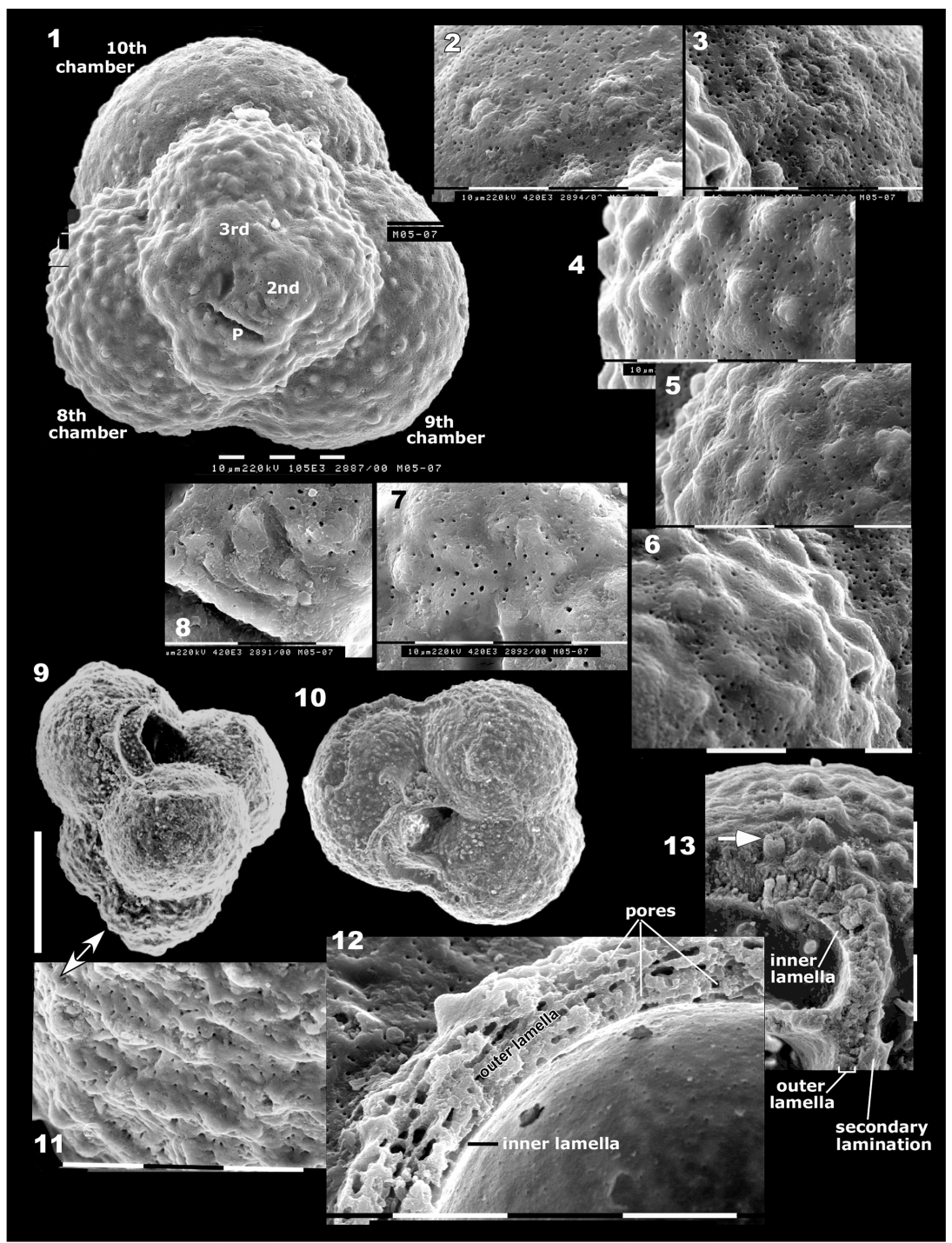

Figure 8. Changes in surface ornament during ontogeny. (1-8) Globuligerina altissapertura n. sp., specimen WAM 19.1/M5-07. (1) Spiral view of test, showing progressive increase in surface ornament on older chambers. Each division of scale bar: $10 \mu \mathrm{m}$. (2) Surface of lastpreserved (10th) chamber to show numerous small pores and scattered widely spaced pseudomuricae; one layer of secondary lamination is evident around pseudomuricae at left. (3) Surface of ninth chamber, showing slightly more surface relief on pseudomuricae; (4) eighth chamber, with pseudomuricae becoming higher, closer spaced and imperforate but with pores in surface between pseudomuricae; (5) seventh chamber, with secondary lamination enlarging some pseudomuricae to the extent that they almost touch adjacent ones; (6) sixth chamber: secondary lamination creates short ridges formed by infilling of hollows between adjacent pseudomuricae. At this stage some pores penetrate the secondary lamination, including the ridge crests. (7) Third chamber, part of the initial whorl: depressions between pseudomuricae being progressively infilled, and the short ridges losing their identity. Scattered, slightly larger pores emerge at the surface. (8) Surface of proloculus at lower left (with a deep scratch cutting across it) and second chamber at upper right. The wall gives the appearance of being greatly thickened, with pseudomuricae as low lumps and ridges. Scattered pores are distributed at random and are larger than those seen on the seventh to 10th chambers. For (1-8) each division of scale bar: $10 \mu \mathrm{m}$. (9-11) Globuligerina bathoniana australiana $\mathrm{n}$. ssp., specimen WAM 18.14/M10-36. (9) Side view; (10) umbilical view, showing the final two chambers broken off. Scale bar: $100 \mu \mathrm{m}$. (11) Detail of early chamber at lower left in (9) to show strong ridge development as the pseudomuricae join; penetrated by numerous pores, presumably some developed during secondary lamination. Each scale bar: $10 \mu \mathrm{m}$. (12) Globuligerina sp., specimen WAM 18.21/M102-03. Broken and naturally etched section through a chamber in the first whorl shows the layered structure of the wall. The "primary" inner and outer lamellae are penetrated by pores (arrowed), but these appear to be increasingly blocked or diverted as further layers are deposited. Each division of scale bar: 10 $\mu \mathrm{m}$. (13) Globuligerina bathoniana australiana n. ssp., specimen WAM 18.17/M51-06, detailed view of wall structure of chamber at top of specimen shown in Fig. 9: 6, a thick-walled specimen with an unknown number of chambers broken off. Shown here is the primary wall of inner and outer lamellae, overlain by secondary lamination that completely covers an earlier-formed pseudomuricae (arrowed). Each division of scale bar: $10 \mu \mathrm{m}$. All specimens are from sample BMR 95/DR7/8. 


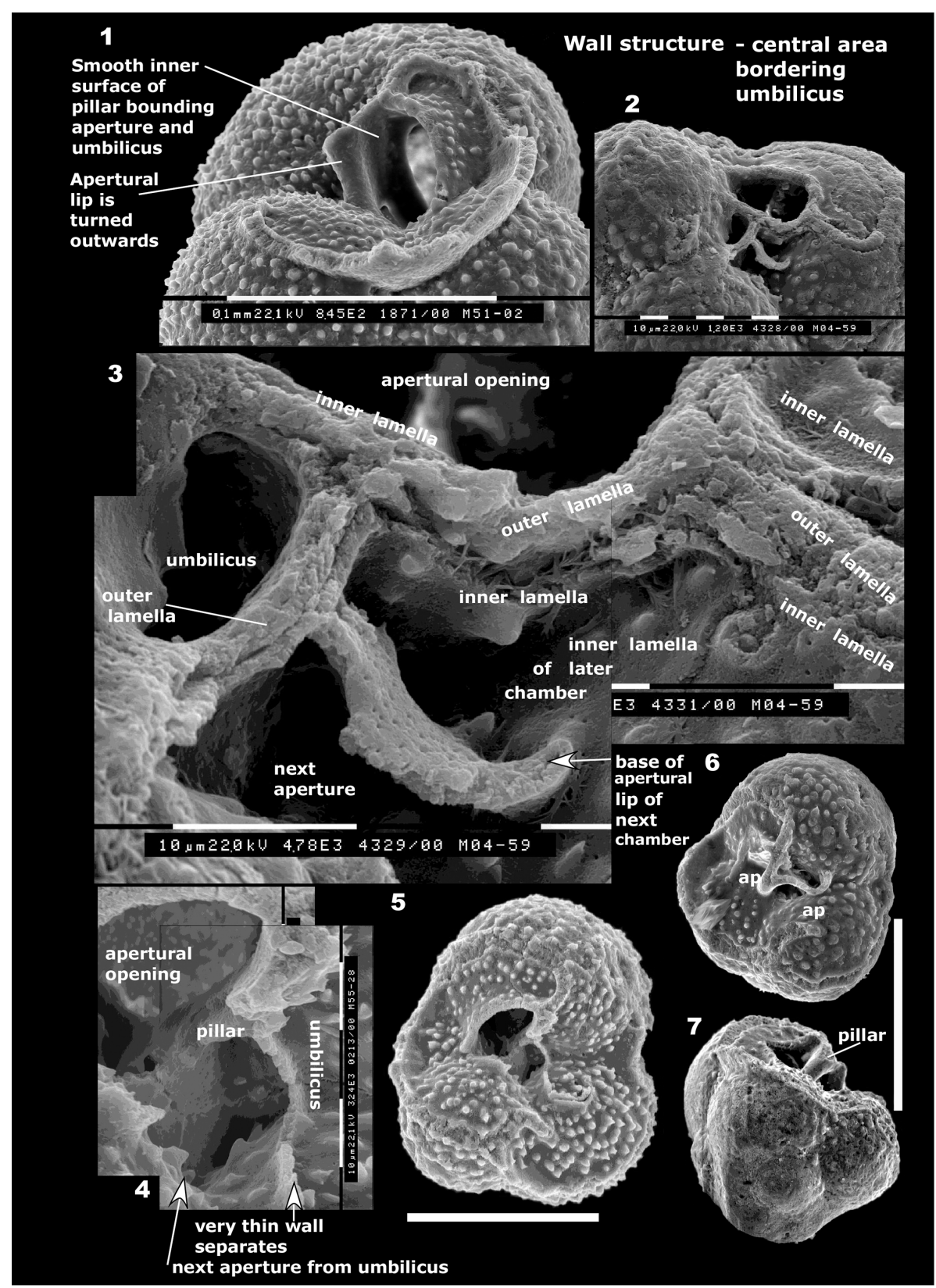

Figure 9. (1) Wall structure in central area bordering umbilicus. Globuligerina altissapertura n. sp., specimen WAM 18.9/M51-02. The broken apertural lip of the final chamber forms a pillar-like structure, contiguous with older apertures. The inner surface of this structure is smooth in this specimen, and the lip is turned outwards (see also Fig. 6: 1-2 for additional photos of the same lip). Scale bar: 100 $\mu$ m. (2-3) Globuligerina altissapertura n. sp., specimen WAM 18.8/M4-59. (2) Umbilical view of part of broken, naturally etched specimen, showing the aperture and scars of the walls of two broken-off chambers; (3) detail of (2). The septum at right between the two broken chambers consists of three layers: inner, outer and inner lamella. Note the inner lamella lining the floor of both chambers. The apertural lip of the earlier aperture (at top) is badly damaged, and the turnover of the lip into the umbilicus is not seen. A curved plate in the lower part of the photo appears to be the rear portion of attachment of the lip of the following aperture. For (2-3), each division of scale bar: $10 \mu \mathrm{m}$. (4-5) Globuligerina bathoniana australiana n. ssp., specimen WAM 18.18/M55-28; (see also Fig. 6: 4-5; Fig. 10: 8-10). (4) Detail of (5), showing the umbilical structures. Aperture of earlier chamber at upper left; the light colour is an imaging aberration, as the view is into the empty space of the chamber. The dark hollow at lower centre is a blind alley behind the pillar, closed off by the apertural lip. Each division of scale bar: $10 \mu \mathrm{m}$. (5) Umbilical view; two chambers are broken off. The broken chamber at left has an aperture that opened towards the lower right, and a very thin wall of curving apertural lip separates the chamber from the umbilicus (see (4)). Scale bar: 100 $\mu \mathrm{m}$. (6-7) Globuligerina bathoniana australiana $\mathrm{n}$. ssp., specimen WAM 18.17/M51-06. (6) Umbilical view of heavily calcified specimen, showing a broken-off chamber, with two successive apertures at $120^{\circ}$, rotating around the robust hollow central pillar structure; (7) specimen tilted away from viewer to show the pillar in side view; top of the earlier aperture is the dark area to the left of the pillar. The scale bar for (6-7) is 100 $\mu \mathrm{m}$. 


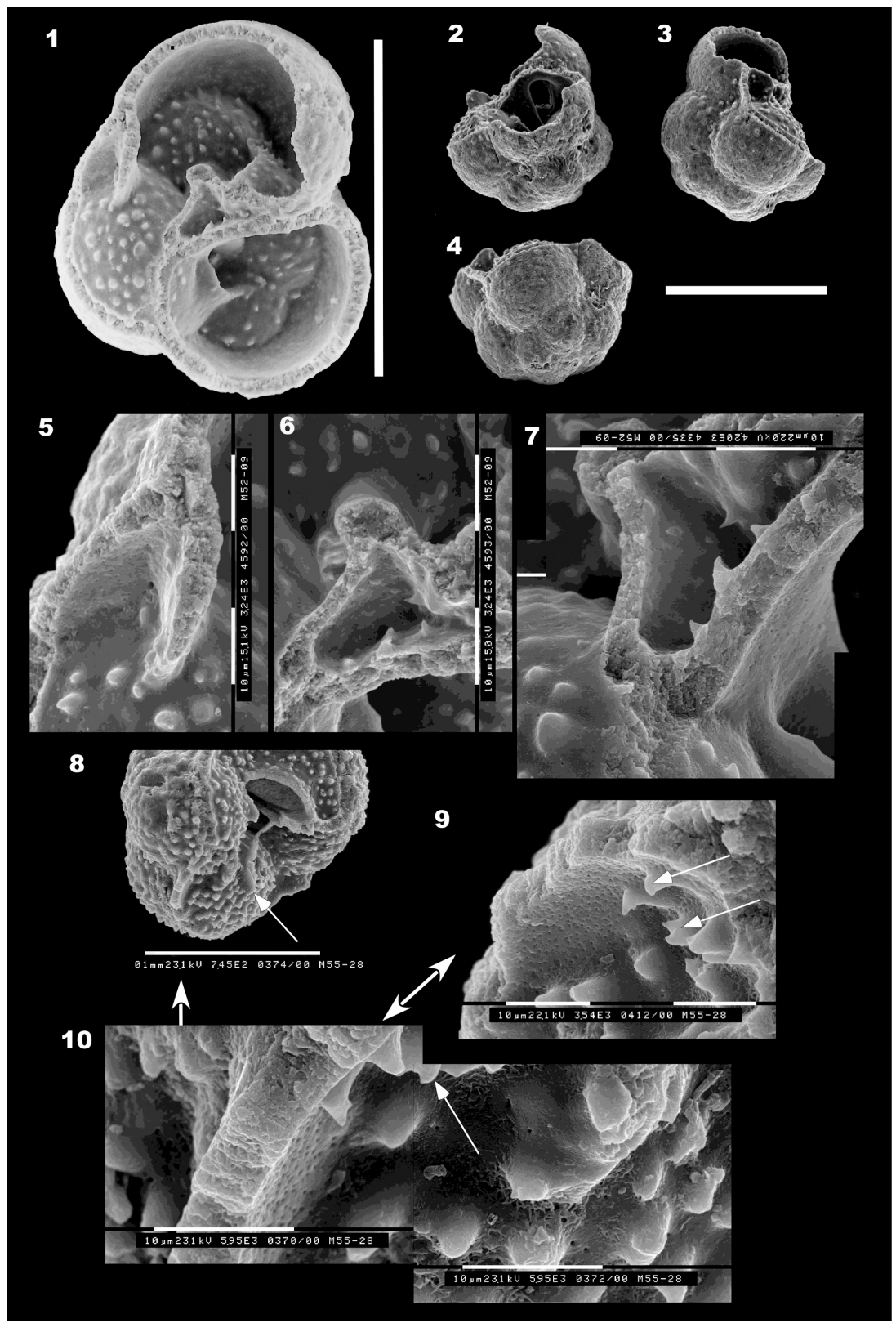

Figure 10. Umbilical structures, apertures and interior of chambers. (1-7) Globuligerina bathoniana australiana n. ssp., specimen WAM 18.20/M52-09. (1) Umbilical overview of broken specimen, showing three apertures, the first two intact with projecting tunnel-like lips, and the third being the broken opening into the chamber at lower left. Scale bar: $100 \mu \mathrm{m}$. (2) Side view from lower right of (1), looking across the broken chamber wall at the inner opening of the aperture (dark arch in black wall), which projects into the chamber at upper left in (1). See also (7). (3) Side view, specimen at same angle but rotated to the left to look at the bottom of the broken third aperture and its lip. Note the almost flat base of the specimen. (4) Oblique view of the very low trochospire of the first whorl. Scale bar for (2-4): 100 $\mu$ m. (5) The peripheral base of the lip of the third aperture, coated by inner lamellae on both sides. (6) The inner edge of the third aperture (at left), the hollow triangular pillar formed by successive apertural lips, and the exit edge of the second aperture at the upper right. (7) Same area as in (6), tilted to show the interior of the arch of the second aperture from the inside of the chamber (at extreme right); plus the top of aperture (1), at bottom right. For (5-7), each division of the scale bar: $10 \mu \mathrm{m}$. (8-10) Globuligerina bathoniana australiana n. ssp., specimen WAM 18.18/M55-28. (8) Specimen tilted to show the broken apertural opening and base of the apertural lips (arrowed), opening into the broken-off final chamber. Scale bar: $100 \mu \mathrm{m}$. (9) Oblique side view, detail of interior wall structure in the hollow between the apertural lip (at right) and outer wall of the next chamber (at left). Note the hook-like tubercules that appear to be attached to the newly formed wall and appear to have formed after the wall. (10) The same fragment of wall as in (9), but viewed from above. The floor of the chamber consists of older tubercules from the whorl below (right side of photo), coated with new inner lamella, which bends upwards to form the porous interior of the new wall (left side of photo). The new hook-like tubercules are visible on the wall surface (arrowed). Each subdivision of scale bar: $10 \mu \mathrm{m}$. 


\section{Remarks}

Although represented by relatively few specimens $(\sim 25)$, this smooth triserial form does not fit within any described Jurassic or Triassic species or genus known to the author. It does not fit within the four Jurassic genera proposed by Simmons et al. (1997), nor does it fit within reticulate-walled Conoglobigerina or pustulose-walled Globuligerina (Gradstein et al., 2017a) on the grounds of its smooth microperforate wall and ornament confined to the area of the bulla. This form does not correspond to any of the genera proposed by Fuchs $(1967,1973)$, which have as a minimum four chambers per whorl. It also does not correspond with Conoglobigerina pupa of Wernli and Görög (2007), which has much more tightly embracing, compressed chambers (not hemispherical chambers) and a higher coil with shallow sutures. "Conoglobigerina” trilocula Wernli and Görög has a much lower spire and a more embracing coil. Conoglobigerina solaperta of Wernli and Görög has some similarities in overall shape, having three chambers in the final whorl, but the coil expands much more slowly than in Mermaidogerina. The aperture also appears to be a low arch in C. solaperta, whereas in Mermaidogerina loopae it is a high asymmetrical virguline opening. In Mermaidogerina the variation in wall appearance seen, from smooth in some specimens, to smooth and slightly pustulose in one, to ridged in another specimen (at very high magnification), suggests that an assignment to either Conoglobigerina or Globuligerina is not possible on the basis of wall ornament, which is a key defining character of these genera. The apparent absence of secondary lamination in Mermaidogerina may explain the virtual absence of pseudomuricae development, in contrast to the other two forms described here.

Mermaidogerina is the first Jurassic recorded manifestation of entirely triserial coiling, later repeated in Guembelitria and Gallitellia; its apertural shape is, however, entirely different to these younger genera, which are also much higher-spired. Examination of Pleistocene-Holocene Gallitellia vivans (to check for the possibility of sea-floor contamination) shows it is very different in test shape (a very high trochospire of loosely appressed chambers), chamber shape (spherical rather than hemispherical), apertural shape and position (a medium, symmetrical umbilical arch without a lip, centrally placed), and wall structure and ornament. The assignment of Mermaidogerina to any benthic genus seems ruled out by the high, looped-shaped aperture, the globular, hemispherical chambers and the presence of a bulla in some specimens. In size it is only slightly smaller than Globuligerina bathoniana australiana and $G$. altissapertura, and as most specimens consist of two whorls, the form is not a juvenile.
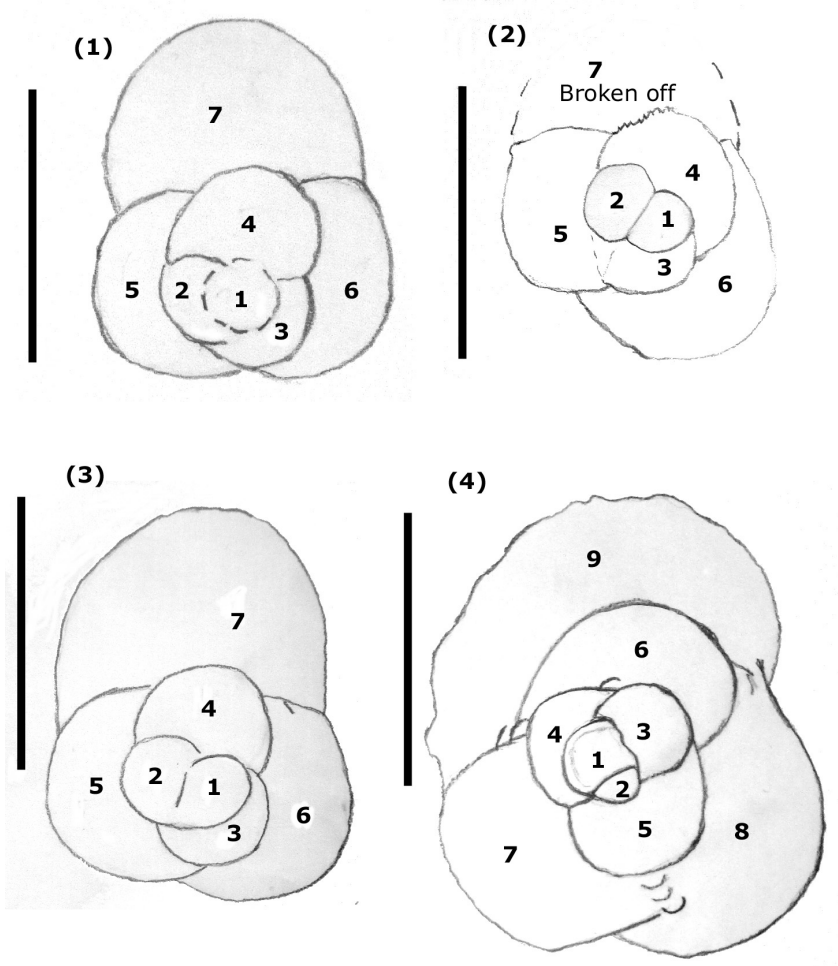

Figure 11. Triserial coiling mode in Mermaidogerina loopae $\mathrm{n}$. gen. n. sp. (1-4). Drawings of spiral views showing triserial chamber arrangement: (1) WAM 18.22/M52-01; (2) WAM 18.25/M5204; (3) WAM 18.23/M11-35; (4) WAM 18.26/M101-08. Scale bars: $100 \mu \mathrm{m}$.

\section{Conclusions}

The three aragonitic planktonic foraminifera species described here from the early Bajocian of the southern Tethys differ from Northern Hemisphere planktonic species most notably in the presence of only three (or occasionally 3.5) chambers in the final whorl. Globuligerina bathoniana australiana described here has only three chambers in the final whorl instead of four. This form also exhibits a smaller range of variation and tighter coiling than specimens included within Bathonian Globuligerina bathoniana by Pazdrowa (1969), and it is more slender and tapering than Globuligerina bathoniana gigantea Wernli and Görög (1999), while having inflated chambers. These morphological differences, the very early Bajocian age, and the fact that the specimens are from south of the Tethyan tropical belt and thousands of kilometres from the nearest previously reported occurrences support the erection of a new subspecies for the Australian form. The new species, Globuligerina altissapertura, has a rapidly expanding test of two whorls with a spire as high as the diameter and a high narrow "virguline-shaped" aperture. It has only three chambers in the final whorl. Secondary lamination has formed prominent pseudomuricae on the walls of both these species. 
The wholly triserial, smooth-walled form with a high looped aperture does not fit into any described genus or species, and a new genus, Mermaidogerina, (type species Mermaidogerina loopae n. gen. n. sp.), is proposed to accommodate it. The presence of an aragonitic wall and the prominent ornament in the area of the bulla suggest that diagenesis is not responsible for the smooth exterior wall texture.

All three taxa have a bulla developed as their final chamber, indicating a planktonic mode of life in at least their reproductive phase. The test ornament of the two species of Globuligerina, identical to that of younger Jurassic planktonic species, also suggests a fully planktonic mode of life. In this respect, these species differ markedly from their suggested Oberhauserella ancestor(s) (as suggested by Hart et al., 2003).

The presence of three forms of planktonic foraminifera on the southern margin of the Tethys by the beginning of the Bajocian indicates that planktonic species were present at this time along continental shelves in the Australian region and were not confined to the Northern Hemisphere.

Data availability. All data pertinent to this paper are given within the paper and in Table 1.

Supplement. Images are shown of unfigured specimens that were measured for inclusion in Table 1. These comprise three specimens of Globuligerina bathoniana australiana (unique specimen identifications are M2-16, M10-30 and M86-19) and three specimens of Globuligerina altissapertura (M10-24, M32-27 and an apertural view of figured WAM19.1/M5-07). The numbers for each image are e.g. M2-16 (specimen number, as in Table 1) and m52-124 (electronic image number). All Supplement specimens are from sample BMR 95/DR7/8 except for M86-19 that is from sample BMR 96/DR28/16 subsample B. The supplement related to this article is available online at: https://doi.org/10.5194/jm-39-93-2020supplement.

Competing interests. The author declares that there is no conflict of interest.

Acknowledgements. The author declares that she has no conflict of interest and has received no financial gain. This research was conducted as part of a $\mathrm{PhD}$ thesis completed by the author part-time at the University of Western Australia in Perth between 1991 and 2003. The university is thanked for a scholarship paying the annual course fees and for the use of a scanning electron microscope at the Department of Microscopy and Microanalysis. David Lynch is thanked for passing on the Cruise 95 dredge samples to the author for further study. Geoscience Australia is thanked for permitting the author to resample the remaining dredge material. Associate Professor David Haig is thanked for continued encouragement to complete the thesis, and Stefan Revets is thanked for stimulating taxonomic discussions. Aleksey Sadekov of the University of Western
Australia is thanked for Raman spectroscopy of several specimens. Ken Apthorpe is thanked for drafting Figs. 1 and 2.

Review statement. This paper was edited by Kirsty Edgar. Malcolm Hart and Ágnes Görög are thanked for providing comments on the first draft of the paper. Two anonymous referees provided stimulating comments on the second draft that improved the paper.

\section{References}

Apthorpe, M.: Towards an Early to Middle Jurassic palaeogeography for the North West Shelf: a marine perspective, in: The Sedimentary Basins of Western Australia: Proceedings of Petroleum Exploration Society of Australia Symposium, edited by: Purcell, P. G. and Purcell, R. R., Perth, 201-210, 1994.

Arkell, W. J. and Playford, P. E.: The Bajocian ammonites of Western Australia, Roy. Soc. Lond. Trans. Ser. B, 237, 547-605, 1954

Bartenstein, H. and Malz, H.: Foraminifera from the Newmarracarra Limestone (Lower Bajocian, W Australia), Senckenbergiana lethaea, 81, 25-57, 2001.

Bignot, G. and Guyader, J.: Observations nouvelles sur Globigerina oxfordiana Grigelis, in: Proceedings of the Second Planktonic Conference, edited by: Farinacci, A., Rome, Edizioni Tecnoscienza, Vol. 1, 79-81, 1971.

Bown, P. R., Cooper, M. K. E., and Lord, A. R.: A calcareous nannofossil biozonation scheme for the early to mid Mesozoic, Newsl. Stratigr., 20, 91-114, 1988.

BouDagher-Fadel, M. K.: Biostratigraphic and Geological Significance of Planktonic Foraminifera, 2nd Edn., UCL Press, London, 2015.

Bradshaw, M. and Yeung, M.: Palaeogeographic Atlas of Australia, Vol. 8, Jurassic, Bureau of Mineral Resources, Australia, 1992.

Chapman, F.: On some Foraminifera and Ostracoda from Jurassic (Lower Oolite) strata near Geraldton, Western Australia, Proc. Roy. Soc. Vict., Melbourne, N.S. 16, part 2, 185-206, plates 22 23, 1904

Colwell, J. B., Graham, T. L., Bradshaw, M., Cadman, S., Shafik, S., and Wells, P.: Stratigraphy of Australia's NW Continental Margin (Project 121-26): Post-cruise Report for BMR Survey 96. Australia, Bureau of Mineral Resources, Geology and Geophysics, Division of Marine Geosciences and Petroleum Geology: BMR Record 1990/85, Canberra, 125 pp., 1990.

Colwell, J. B., Rohl, U., von Rad, U., and Kristan-Tollmann, E.: Mesozoic sedimentary and volcaniclastic rocks dredged from the northern Exmouth Plateau and Rowley Terrace, offshore northwest Australia. AGSO J. Austr. Geol. Geophys., 15, 11-42, 1994.

DeCarlo, T. M., Comeau, S., Cornwall C. E., Gajdzik, L., Guagliardo, P., Sadekov, A., Thillainath, E. C., Trotter, J., and McCulloch, M. T.: Investigating marine bio-calcification mechanisms in a changing ocean with in vivo and high-resolution ex vivo Raman spectroscopy, Glob. Change Biol., 2019, 1-12, https://doi.org/10.1111/gcb.14579, 2019.

Exon, N. F. and Colwell, J. B.: Geological history of the outer North West Shelf of Australia: a synthesis, AGSO J. Austr. Geol. Geophys., 15, 177-190, 1994.

Exon, N. F., Ramsay, D. C., Graham, T., Lynch, D., Miller, H., Petkovic, P., Shafik, S., and West, B.: Postcruise Report: BMR 
Cruise 95: Triassic and Jurassic sequences of the Northern Exmouth Plateau and Offshore Canning Basin. Australia, Bureau of Mineral Resources, Geology and Geophysics, Division of Marine Geosciences and Petroleum Geology, BMR Record 1990/57, Canberra, 76 pp., 1990.

Exon, N. F. and von Rad, U.: The Mesozoic and Cainozoic sequences of the Northwest Australian margin, as revealed by ODP core drilling and related studies, in: The Sedimentary Basins of Western Australia: Proceedings of Petroleum Exploration Society of Australia Symposium, edited by: Purcell, P. G. and Purcell, R. R., Perth 1994, 181-199, 1994.

Fuchs, W.: Über Ursprung und Phylogenie der Trias"Globigerinen" und die Bedeutung dieses Formenkreises für das echte Plankton, Verhandlungen Geol. Bundesanst, 1/2, 135-176, 1967.

Fuchs, W.: Ein Beitrag zur Kenntnis der Jura-"Globigerinen" und verwandter Formen an Hand polnischen materials des Callovien und Oxfordien, Verhandlungen Geol. B.-A., 3, 445-487, 1973.

Görög, Á.: Early Jurassic planktonic foraminifera from Hungary, Micropaleontology, 40, 255-260, 1994.

Gradstein, F. M.: The planktonic foraminifera of the Jurassic, Part III: annotated historical review and references, Swiss J. Palaeontol., 136, 273-285, 2017.

Gradstein, F., Gale, A., Kopaevich, L., Waskowska, A., Grigelis, A., and Glinskikh, L.: The planktonic foraminifera of the Jurassic, Part I: material and taxonomy, Swiss J. Palaeontol., 136, 187257, 2017a.

Gradstein, F., Gale, A., Kopaevich, L., Waskowska, A., Grigelis, A., Glinskikh, L., and Görög, Á.: The planktonic foraminifera of the Jurassic, Part II: Stratigraphy, palaeoecology and palaeobiogeography, Swiss J. Palaeontol., 136, 259-271, 2017 b.

Grigelis, A. A.: Globigerina oxfordiana sp. n. - occurrence of globigerines in the Upper Jurassic deposits of Lithuania, Nauchnyye Doklady Vysshey Shkoly, Geologo-Geograficheskie Nauki, Moscow, 1958, 3, 109-111, 1958 (in Russian).

Grigelis, A. A.: Globuligerina oxfordiana (Grigelis, 1958) - revision of the first planktonic foraminifera discovered in the Upper Jurassic of Lithuania, Geologija, Geografija, 2016, T.2, Nr. 2, 62$83,2016$.

Grigelis, A. and Gorbatchik, T.: Morphology and Taxonomy of Jurassic and Early Cretaceous representatives of the Superfamily Globigerinacea (Favusellidae), J. Foramin. Res., 10, 180-190, 1980.

Haig, D. W., Mory, A. J., McCartain, E., Backhouse, J., Hakansson, E., Ernst, A., Nicoll, R. S., Shi, G. R., Bevan, J. C., Davydov, V. I., Hunter, A. W., Keep, M., Martin, S. K., Peyrot, D., Kossavaya, O., and Dos Santos, Z.: Late Artinskian-Early Kungurian (Early Permian) warming and maximum marine flooding in the East Gondwana interior rift, Timor and Western Australia, and comparisons across East Gondwana, Palaeogeogr. Palaeocl., 468, 88-121, 2017.

Hart, M. B., Oxford, M. J., and Hudson, W.: The early evolution and palaeobiogeography of Mesozoic planktonic foraminifera, Geol. Soc., Lond. Spec. Publ., Vol. 194, 115-125, 2002.

Hart, M. B., Hylton, M. D., Oxford, M. J., Price, G. D., Hudson, W., and Smart, C. W.: The search for the origin of the planktic Foraminifera, J. Geol. Soc. Lond., 160, 341-343, 2003.

Hart, M. B., Hudson, W., Smart, C. W., and Tyszka, J.: A reassessment of 'Globigerina bathoniana' Pazdrowa, 1969 and the palaeoceanographic significance of Jurassic planktic foraminifera from southern Poland, J. Micropalaeontol., 31, 97109, https://doi.org/10.1144/0262-821X11-015, 2012.

Helby, R., Morgan, R., and Partridge, A. D.: A palynological zonation of the Australian Mesozoic, in: Studies in Australian Mesozoic Palynology, edited by: Jell, P. A., Association of Australasian Palaeontologists, Memoir, 4, 1-94, 1987.

Hocking, R. M.: Jurassic deposition in the Southern and Central North West Shelf, Western Australia. Geological Survey of Western Australia, Record 1992/7, 101 pp., 1992.

Huddleston, R. W.: Comments on the nomenclatural status of the families Caucasellidae and Favusellidae (Foraminiferida), P. Biol. Soc. Wash., 95, 637-638, 1982.

Johnson, B. D., Powell, C. McA., and Veevers, J. J.: Spreading history of the eastern Indian Ocean and Greater India's northward flight from Antarctica and Australia, Geol. Soc. Am. Bull., 87, 1560-1566, 1976.

Kristan-Tollmann, E. and Gramann, F.: Paleontological evidence for the Triassic age of rocks dredged from the northern Exmouth Plateau (Tethyan foraminifers, echinoderms and ostracodes), in: Proceedings of the Ocean Drilling Program, edited by: von Rad, U., Haq, B. U., Kidd, R. B., and O'Connell, S., Scientific Results Leg 122, College Station, Texas, 463-474, 1992.

Metcalfe, I.: Gondwana dispersion and Asian accretion: Tectonic and palaeogeographic evolution of eastern Tethys, J. Asian Earth Sci., 66, 1-33, 2013.

Morozova, V. G. and Moskalenko, T. A.: Planktonic foraminifera from the Bajocian-Bathonian boundary in central Dagestan (northeastern Caucasus), Voprosy Mikropaleontologii, 5, 3-30, 1961 (in Russian).

Pazdrowa, O.: Bathonian Globigerina of Poland, Rocznik Polskiego Towarzystwa Geologicznego (Annales de la Société Géologique de Pologne), vol. XXXIX, Krakow, 41-56, 1969.

Powell, C. McA., Johnson, B. D., and Veevers, J. J.: A revised fit of East and West Gondwanaland, Tectonophysics, 63, 13-29, 1980.

Quilty, P. G.: Early Jurassic Foraminifera from the Exmouth Plateau, Western Australia, J. Paleontol., 55, 985-995, 1981.

Shafik, S.: Significance of calcareous nannofossil-bearing Jurassic and Cretaceous sediments on the Rowley Terrace, offshore northwest Australia, AGSO J. Austr. Geol. Geophys., 15, 71-88, 1994.

Simmons, M. D., BouDagher-Fadel, M. K., Banner, F. T., and Whittaker, J. E.: The Jurassic Favusellacea, the earliest Globigerinina, BouDagher-Fadel, M. K., Banner, F. T., Whittaker, J. E., Simmons, M. D., and Taylor, H., in: The Early Evolutionary History of Planktonic Foraminifera, Chapman and Hall, London, 17-51, 1997.

Stagg, H. M. J. and Exon, N. F.: Geology of the Scott Plateau and Rowley Terrace, off northwestern Australia. Australia, Department of National Development and Energy, Bureau of Mineral Resources, Geology and Geophysics, Bulletin 213, Australian Government Publishing Service, Canberra, 67 pp., 1981.

Stam, B.: Quantitative analysis of Middle and Late Jurassic foraminifera from Portugal and its implications for the Grand Banks of Newfoundland, Utr. Micropal. Bull., 34, 167 pp. 1986.

Veevers, J. J. and Cotterill, D.: Western margin of Australia: Evolution of a rifted arch system, Geol. Soc. Am. Bull. 89, 337-355, 1978. 
Wernli, R.: Les protoglobigérines (foraminifères) du Toarcien et de l'Aalénien du Domuz Dag (Taurus Occidental, Turquie), Ec. Geol. Helvet, 81, 661-668, 1988.

Wernli, R.: Les foraminifères globigériniformes (Oberhauserellidae) du Toarcien inférieur de Teysachaux (Préalpes médianes, Fribourg, Suisse), Revue de Paléobiologie, 14, 257-269, 1995.
Wernli, R. and Görög, Á.: Protoglobigerinids (Foraminifera) acid extracted from Bajocian limestones (Hungary), Rev. Esp. Micropal., 31, 419-425, 1999.

Wernli, R. and Görög, Á.: Determination of Bajocian protoglobigerinids (Foraminifera) in thin sections, Revue de Paléobiologie, 19, 399-407, 2000.

Wernli, R. and Görög, Á.: Protoglobigérines et Oberhauserellidae (Foraminifères) du Bajocien-Bathonien du Jura méridional, France, Revue de Micropaléontologie, 50, 185-205, 2007. 